\title{
Soil replacement combined with subsoiling improves cotton yields
}

\author{
LI Pengcheng ${ }^{1 \dagger}$, WANG Shulin ${ }^{2 \dagger}$, Ql Hong ${ }^{2}$, WANG Yan ${ }^{2}$, ZHANG Qian², FENG Guoyi ${ }^{2}$, ZHENG Cangsong ${ }^{1}$, \\ YU Xueke', LIN Yongzeng ${ }^{2^{*}}$ and DONG Helin ${ }^{1^{*}}$
}

\begin{abstract}
Background: Long-term rotary tillage has led to the deterioration of cotton production in northern China. This deterioration is due to the disturbance of topsoil, a dense plough pan at the $20-50 \mathrm{~cm}$ depth, and the decreased water storage capacity. A 2-yr field experiment was performed from 2014 to 2015 to explore a feasible soil tillage approach to halting the deterioration. The experiment consisted of four treatments: replacing the topsoil from the 0-15 cm layer with the subsoil from the $15-30 \mathrm{~cm}$ layer $(T 1)$; replacing the topsoil from the $0-20 \mathrm{~cm}$ layer with the subsoil from the $20-40 \mathrm{~cm}$ layer and subsoiling at the $40-55 \mathrm{~cm}$ layer (T2); replacing the topsoil from the $0-20 \mathrm{~cm}$ layer with the subsoil from the $20-40 \mathrm{~cm}$ layer and subsoiling at the $40-70 \mathrm{~cm}$ layer (T3); and conventional surface rotary tillage within $15 \mathrm{~cm}$ as the control (CK).

Results: The results indicated that the soil bulk densities at the $20-40 \mathrm{~cm}$ layer in T2 were $0.13 \mathrm{~g} \cdot \mathrm{cm}^{-3}$ and 0.15 $\mathrm{g} \cdot \mathrm{cm}^{-3}$ lower than those obtained from CK in 2014 and 2015, respectively. The total nitrogen (N) and the available phosphorus (P) and potassium (K) contents from the 20-40 cm layer in T2 and T3 were significantly higher than those in CK and T1. The amount of soil water stored in the $0-40 \mathrm{~cm}$ layer of $\mathrm{T} 2$ at the squaring stage of cotton was $15.3 \mathrm{~mm}$ and $13.4 \mathrm{~mm}$ greater than that in CK in 2014 and 2015, respectively, when the weather was dry.

Compared with CK, T2 increased cotton lint yield by 6.1 and 10.2 percentage points in 2014 and 2015, respectively, which was due to the improved roots within the $20-60 \mathrm{~cm}$ layer, the greater number of bolls per plant and the higher boll weight in the T2 treatment.

Conclusions: The results suggested that soil replacement plus subsoiling would be a good alternative to current practices in order to break through the bottleneck constraining cotton production in northern China. Replacing the topsoil in the $0-20 \mathrm{~cm}$ layer with the soil from the $20-40 \mathrm{~cm}$ layer plus subsoiling at the $40-55 \mathrm{~cm}$ layer would be the most effective method.
\end{abstract}

Keywords: Soil replacement, Subsoiling, Cotton, Yield, Soil nutrients

\section{Background}

Cotton is one of the primary cash crops in the Yellow River Valley of China. In this area, rotary tillage is a normal practice in cotton production (Dai and Dong 2014). However, continuous rotary tillage has caused problems, such as severe Verticillium wilt disease, premature cotton senility and yield reduction (Dong et al. 2012),

\footnotetext{
*Correspondence: zaipei@sohu.com; donghl668@sina.com

${ }^{+} \mathrm{Li} P \mathrm{PC}$ and Wang SL contributed equally to this work.

${ }^{2}$ Institute of Cotton, Hebei Academy of Agriculture and Forestry Sciences/Key Laboratory of Biology and Genetic Improvement of Cotton in Huanghuaihai Semiarid Area, Ministry of Agriculture/National Cotton Improvement Center Hebei Branch, Shijiazhuang 050051, Hebei, China

'Institute of Cotton Research of Chinese Academy of Agricultural Sciences, State Key Laboratory of Cotton Biology, Anyang 455000, Henan, China
}

inhibition of cotton root growth (Salih et al. 1998; Kennedy and Hutchinson 2001; Busscher and Bauer 2003), and vigorous weed growth (Wayne et al. 2005; Clewis et al. 2006; Aulakh et al. 2011). The effects of different tillage practices on soil moisture, crop growth, and soil physical and chemical properties have been evaluated (Rickerl and Touchton 1986; Salinas-Garcia et al. 1997; Karamanos et al. 2004). Deep tillage can increase pores in the soil bulk, helping to store enough rainwater during the fallow period (Wesley et al. 2001; Khalilian et al. 2000). The deep tillage of cotton fields can effectively reduce the occurrence of Verticillium wilt (Patrick et al. 1959). However, with rising energy costs, expensive deep tillage needs to be re-evaluated (Busscher et al. 2012).

(c) The Author(s). 2019 Open Access This article is distributed under the terms of the Creative Commons Attribution 4.0 International License (http://creativecommons.org/licenses/by/4.0/), which permits unrestricted use, distribution, and 
Subsoiling breaks through the plough pan, leading to a significant decrease in soil bulk density (Harrison et al. 1994) and an increase in root growth in the deeper soil (Raper et al. 2007; Li et al. 2013), as well as improves crop photosynthesis, aboveground vegetative growth, and yield formation during the late growth period (Akinci et al. 2004; Borghei et al. 2008). Zheng et al. (2011) found that subsoiling plus rotary tillage could enhance the water utilization efficiency of wheat crops and facilitate the distribution of dry matter towards the grains (Yang et al. 2013). Therefore, we proposed a new soil tillage method that changes the tilth layer structure by completely replacing the topsoil with deep soil and performing deeper subsoiling. We hypothesized that the proposed soil replacement with subsoiling could benefit continuous cotton production.

\section{Materials and methods}

\section{Field experiments}

A 2-yr experiment was conducted in a randomized complete block design in 2014 and 2015 at the Experimental Station of Hebei Academy of Agriculture and Forestry Sciences in Wei County, Hebei province $\left(36^{\circ} 98^{\prime} \mathrm{N}, 115^{\circ} 25^{\prime} \mathrm{E}\right)$. Cotton was planted as a monocrop for more than 20 years, and the soil in the top 20 $\mathrm{cm}$ contained organic matter $9.4 \mathrm{~g} \cdot \mathrm{kg}^{-1}$, total $\mathrm{N} 0.655$ $\mathrm{mg} \cdot \mathrm{kg}^{-1}$, available P $21.6 \mathrm{mg} \cdot \mathrm{kg}^{-1}$, and available K 163 $\mathrm{mg} \cdot \mathrm{kg}^{-1}$ in 2014 , and $7.6 \mathrm{~g} \cdot \mathrm{kg}^{-1}, 0.504 \mathrm{mg} \cdot \mathrm{kg}^{-1}, 18.5$ $\mathrm{mg} \cdot \mathrm{kg}^{-1}$, and $115 \mathrm{mg} \cdot \mathrm{kg}^{-1}$, respectively, in 2015 . The experiment set up 4 treatments with 3 replicates: rotary tillage of the top $15 \mathrm{~cm}(\mathrm{CK})$; replacement of the topsoil from the $0-15 \mathrm{~cm}$ layer with the subsoil from 15 to 30 cm layer (T1); replacement of the topsoil from the 0-20 $\mathrm{cm}$ layer with the subsoil from the $20-40 \mathrm{~cm}$ layer plus subsoiling the $40-55 \mathrm{~cm}$ layer (T2); and replacement of the top soil from the $0-20 \mathrm{~cm}$ layer with the subsoil from 20 to $40 \mathrm{~cm}$ layer plus subsoiling the $40-70 \mathrm{~cm}$ layer (T3). For T2, the soil within the $0-20 \mathrm{~cm}$ layer was collected and set aside, and the soil within the $20-40 \mathrm{~cm}$ layer was collected and set in a separate pile. The soil in the $40-55 \mathrm{~cm}$ layer was loosened using a shovel; the soil that had been set aside from the $0-20 \mathrm{~cm}$ layer was then added back in first, and the soil from the $20-40 \mathrm{~cm}$ layer was added as the topsoil. Similar procedures were conducted for T1 and T3. The experiment was performed in separate fields for 2 years.

The plot size was $33.6 \mathrm{~m}^{2}(5.6 \mathrm{~m} \times 6.0 \mathrm{~m})$. The plots were treated with rotary tillage and soil replacement plus subsoiling on 10th April and were fertilized with $\mathrm{N}$ : $\mathrm{P}_{2} \mathrm{O}_{5}: \mathrm{K}_{2} \mathrm{O}=15: 13: 17$ (750 $\left.\mathrm{kg} \cdot \mathrm{hm}^{-2}\right)$ and then flooded $\left(1200 \mathrm{~m}^{3} \cdot \mathrm{hm}^{-2}\right)$ on 16th April in both seasons. Cotton (G. hirsutum L. vs Jiza 2) seeds were sown on 25th April, and the field was mulched with plastic film in both years. The plant density was 57150 plants.hm ${ }^{-2}$ at a wide-narrow row spacing of $95 \mathrm{~cm}$ and $45 \mathrm{~cm}$ and a plant spacing of $25 \mathrm{~cm}$. The plants were irrigated once on 16th July 2014, at $600 \mathrm{~m}^{3} \cdot \mathrm{hm}^{-2}$, and twice on 2nd July and 1st August 2015 at $300 \mathrm{~m}^{3} \cdot \mathrm{hm}^{-2}$ each time. Other management practices, including pest and weed control, were conducted according to local agronomic practices. The rainfall during the cotton growth stage is shown in Fig. 1.

\section{Sample collection and measurements}

Soil samples were collected using a soil auger $(2.5 \mathrm{~cm}$ in diameter) at 3 days after sowing (DAS) (28th April), the seedling stage (13th May, 18 DAS), the squaring stage (13th June, 49 DAS), the flowering stage (13th July, 69 DAS), the boll formation stage (13th August, 110 DAS), and the boll opening stage (23rd October, 181 DAS). Five soil columns of $80 \mathrm{~cm}$ were sampled from each plot in a zig-zag formation, and the column was divided into 4 segments (subsamples) with $20 \mathrm{~cm}$ intervals. The soil columns were mixed by hand and weighed to determine the fresh weight. The soil water content was determined by drying the soil columns in an oven at $105^{\circ} \mathrm{C}$ until they reached a constant weight (Salih et al. 1998).

The soil chemical properties were determined, including the organic matter, total $\mathrm{N}$, available $\mathrm{P}$, and available K contents (Holliday 1986). Soil organic matter was determined by potassium dichromate wet combustion, and the total $\mathrm{N}$ was measured by the Kjeldahl method. The available $\mathrm{P}$ was extracted with $0.5 \mathrm{~mol} \cdot \mathrm{L}^{-1} \mathrm{NaHCO}_{3}$ at $\mathrm{pH} 8.5$ and measured by using the molybdenum blue method. The available $\mathrm{K}$ was extracted with $1 \mathrm{~mol} \cdot \mathrm{L}^{-1}$ $\mathrm{CH}_{3} \mathrm{COONH}_{4}$ at $\mathrm{pH} 7$ and measured by flame atomic absorption spectroscopy. The soil column collected on 13th July was used for the bulk density determination by using an aluminium box $(5 \mathrm{~cm}$ in diameter, $5 \mathrm{~cm}$ in height) to pack 1 out of 4 sub-subsamples from each subsample at $5 \mathrm{~cm}$ intervals. The bulk density of each subsample was calculated by dividing the weight of the dried soil by the volume of the soil after averaging the 4 sub-subsamples (Holliday 1986).

The soil water stored $(S W S)$ within different soil layers was calculated by using the formula $S W S_{i}=W_{i} \times D_{i} \times$ $H_{i} \times 10 / 100$, where $S W S_{i}(\mathrm{~mm})$ is the soil water stored within soil layer $i, W_{i}$ is the soil water content in soil layer $i, D_{i}$ is the soil bulk density, and $H_{i}$ is the thickness of the soil.

The soil water consumption $(S W C)$ during the growth stages was calculated from the $0-80 \mathrm{~cm}$ soil layer and was calculated by using the formula $S W C=S W S_{f}-S W S_{i}+$ $R+I$, where $S W C(\mathrm{~mm})$ is the water consumption during a growth stage, $S W S_{f}$ is the soil water stored at the final stage of growth, $S W S_{i}$ is the water stored at the initial stage of growth, $R$ is the rainfall during the growth stage, and $I$ is the irrigation water during the growth 


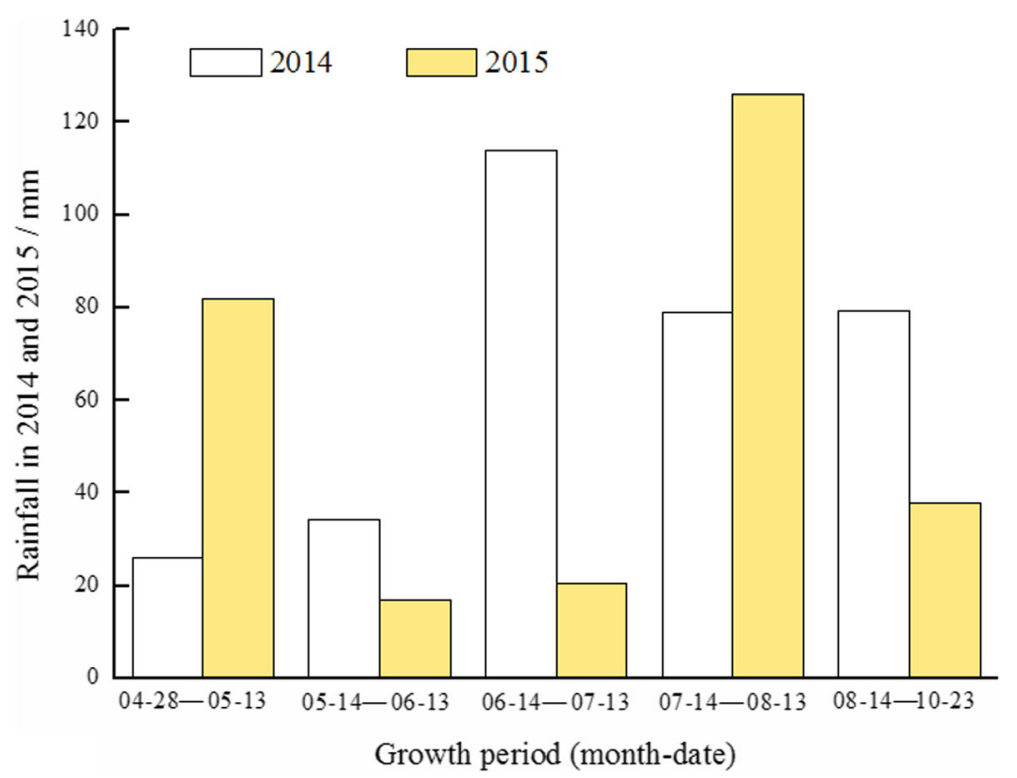

Fig. 1 Rainfall during the cotton growth stages in 2014 and 2015

stage. $S W C$ includes surface evaporation, plant transpiration, and water infiltration. Given that no heavy rainfall occurred during the cotton growth stage, water infiltration was not analysed during this study.

\section{Root traits of cotton}

Root samples were collected at the boll opening stage (13th October, 181 DAS). The roots of 3 cotton plants were randomly collected from the different rows of each plot. The soil column $(25 \mathrm{~cm} \times 40 \mathrm{~cm})$ around a cotton plant was collected from the $0-20,20-40$, and $40-60 \mathrm{~cm}$ tilth layers. The soil was removed carefully by using hand implements and then placed in a circular grid mesh sieve with a diameter of $0.05 \mathrm{~cm}$ and washed under running water to remove the soil particles from the roots. The collected root samples were scanned with a scanner (Phantom 9 800X, Microtek, Shanghai, China) and analysed using WinRHIZO (version 5.0, Régal Instruments Inc.) to determine the root length, average root diameter, and root surface area. The dry matter weight of the roots was determined after drying the root samples in an oven at $80^{\circ} \mathrm{C}$ until a constant weight was reached.

\section{Dry matter weight of aboveground cotton plants and weeds in the field}

Five cotton plants were randomly collected from different rows in each plot at the seedling stage (15th May, 20 DAS) and the budding stage (13th June, 49 DAS). Three cotton plants were randomly collected from different rows in each plot at the initial flowering stage (13 July, 79 DAS), the boll formation stage (13th August, 110
DAS), and the boll opening stage (10th September, 138 DAS). The cotton plant samples were dried in an oven at $80^{\circ} \mathrm{C}$ until a constant weight was reached. The weeds in each plot $(1 \mathrm{~m} \times 2.8 \mathrm{~m})$ were collected at the seedling stage (13th May, 18 DAS), the initial flowering stage (13th June, 79 DAS), and the boll opening stage (23rd October, 181 DAS) and then dried in an oven at $80^{\circ} \mathrm{C}$ to a constant weight and weighed.

\section{Disease and presenility index}

A total of 50 similar cotton plants from each plot were chosen to examine the disease and presenility index $(D P I)$ at the boll opening stage (10th September, 138 DAS). The DPI consists of 5 grades according to the extent of premature senescence and Verticillium wilt in cotton leaves: Grade 0 indicates the absence of yellow or diseased leaves in the cotton plant; Grade 1 indicates that the ratio of yellow leaves or diseased leaves is less than 25\%; Grade 2 indicates that the ratio of yellow leaves or diseased leaves is greater than $25 \%$ but less than 50\%; Grade 3 indicates that the ratio of yellow leaves or diseased leaves is greater than $50 \%$ but less than $75 \%$; and Grade 4 indicates that the ratio of yellow leaves or diseased leaves is greater than $75 \%$. The DPI was calculated by using the following equation: $D P I=\left(1^{*}\right.$ $\left.N_{1}+2^{*} N_{2}+3^{*} N_{3}+4 * N_{4}\right) /\left(4 * N_{t}\right)$, where DPI is the disease and presenility index, $N_{1}$ is the number of leaves classified as Grade 1, $N_{2}$ is the number of leaves classified as Grade 2, $N_{3}$ is the number of leaves classified as Grade $3, N_{4}$ is the number of leaves classified as Grade 4, and $N_{t}$ is the total number of leaves classified as Grade $t$. 


\section{Yield and yield components}

A total of 20 similar cotton plants from each plot were chosen to determine the total number of bolls at the boll opening stage (10th October, 138 DAS). Seed cotton from the middle 6 rows of each plot with an area of $25.2 \mathrm{~m}^{2}$ was harvested by hand before 20th October. The boll weight was calculated by dividing the total weight of the seed cotton by the number of bolls. The lint yields and cracked bolls were determined after ginning with a laboratory gin (MPSY-100A). The lint percentage (lint weight/ seed cotton weight) was determined by harvesting all the bolls and weighing them after drying at each harvest.

\section{Statistical analysis}

A data analysis was performed using the GLMIX function in SAS software (Version 8.1). The initial combined data showed interactions with the year. Thus, all the data are presented separately for each year. The characteristics of the different treatments were compared using the least significant difference at $P<0.05$.

\section{Results}

Effects of soil replacement plus subsoiling on the soil physical and chemical properties

\section{Soil bulk density}

Soil replacement plus subsoiling significantly decreased the soil bulk density in different tilth layers in both seasons (Fig. 2). In CK, the soil bulk density in the 20 $40 \mathrm{~cm}$ layer was greater than that in the other tilth layers. Under the soil replacement plus subsoiling treatments, the soil bulk density from 20 to $40 \mathrm{~cm}$ exhibited the greatest reduction, indicating that soil replacement plus subsoiling had a significant effect on breaking the plough bottom. In T1, the soil bulk density within different tilth layers changed slightly; however, the soil bulk density of $40-60$ and $40-80 \mathrm{~cm}$ layers in T2 and T3, respectively, decreased significantly as the soils in the 50 and $70 \mathrm{~cm}$ tilth layers were loosened in $\mathrm{T} 2$ and $\mathrm{T} 3$.

The treatments were as follows: T1 (replacing the topsoil from 0 to $15 \mathrm{~cm}$ with the subsoil from 15 to $30 \mathrm{~cm}$ ), T2 (replacing the topsoil from 0 to $20 \mathrm{~cm}$ with the subsoil from 20 to $40 \mathrm{~cm}$ plus subsoiling at the $40-55 \mathrm{~cm}$ layer), T3 (replacing the topsoil from 0 to $20 \mathrm{~cm}$ with the subsoil from 20 to $40 \mathrm{~cm}$ plus subsoiling at the $40-70 \mathrm{~cm}$ layer) and CK (rotary tillage within $15 \mathrm{~cm}$ ). Different lowercase letters indicate significant differences between treatments within the same year.

\section{Stored soil water and water consumption}

The total soil water stored within the $0-80 \mathrm{~cm}$ tilth layer after sowing varied only slightly in both seasons (Fig. 3). However, soil replacement plus subsoiling increased the soil water stored within the subsoil. The soil water stored within the $40-60 \mathrm{~cm}$ layer of T2 and T3 increased

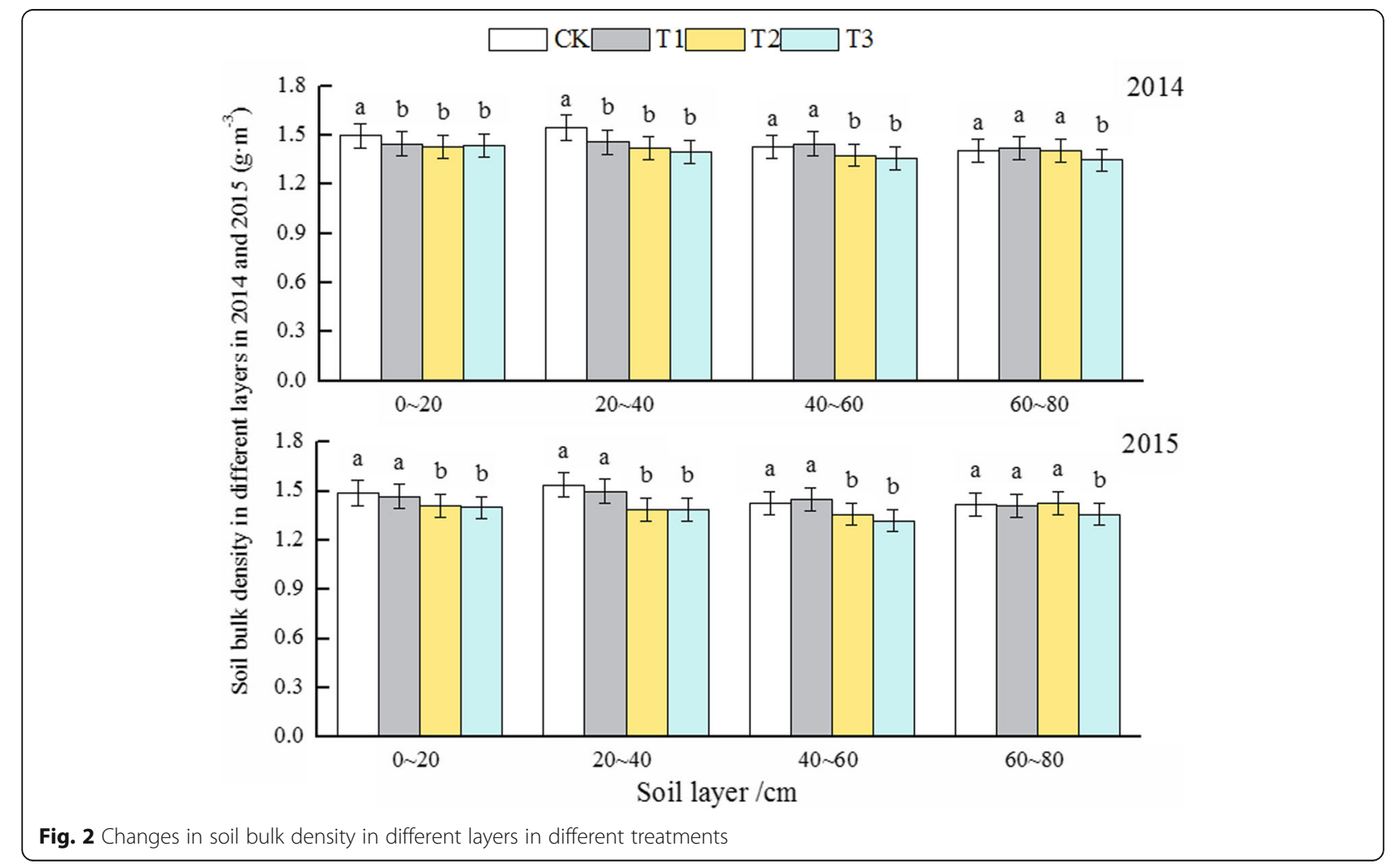




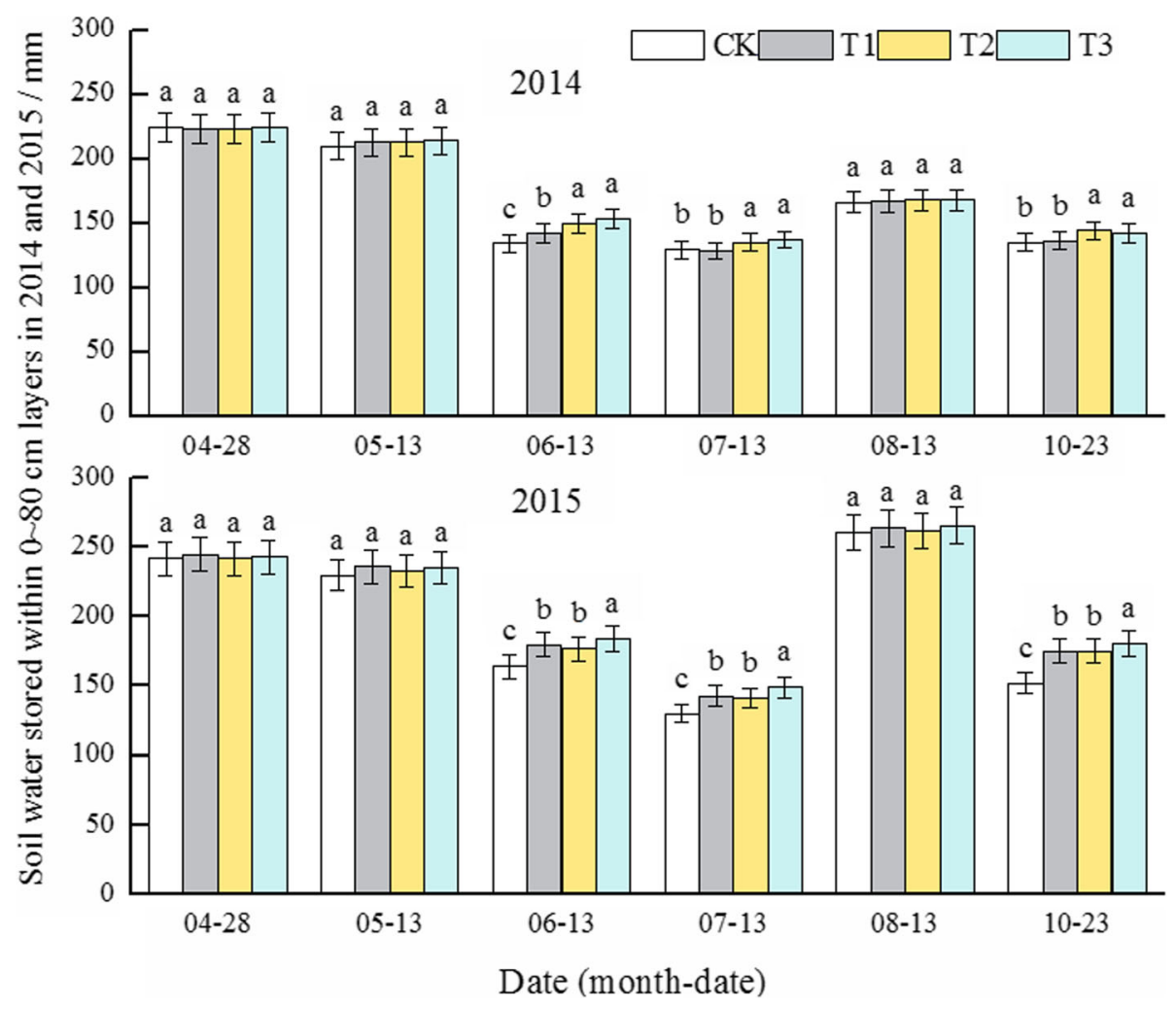

Fig. 3 Changes in soil water stored within the $0-80 \mathrm{~cm}$ layers at different cotton growth stages

by $3.5 \mathrm{~mm}$ and $2.9 \mathrm{~mm}$ in 2014 and by $6.7 \mathrm{~mm}$ and 5.9 $\mathrm{mm}$ in 2015, respectively, relative to that of CK. The soil water stored within the $60-80 \mathrm{~cm}$ layer for T2 and T3 increased by $5.5 \mathrm{~mm}$ and $7.0 \mathrm{~mm}$ in 2014 and by $3.4 \mathrm{~mm}$ and $3.5 \mathrm{~mm}$ in 2015, respectively, relative to that of CK. Long-term rotary tillage formed the bottom of the plough layer and hindered water infiltration so that soil water was primarily concentrated in the $0-20$ and $20-$ $40 \mathrm{~cm}$ tilth layers before sowing.

The soil water stored during the seedling stage (13th May, 18 DAS) decreased slightly after sowing (Table 1 ). Compared with any of the three soil replacement plus subsoiling treatments, CK exhibited a reduction in soil water. In CK, the soil water stored in the $0-20 \mathrm{~cm}$ layer exhibited the largest decrease; it had less soil water than the $0-20 \mathrm{~cm}$ layer of any of the three soil treatments, and there was a small difference between CK and T1 in 2014. Among all the treatments, $\mathrm{T} 1$ had the most soil water stored in the $20-40 \mathrm{~cm}$ layer in both seasons. There were no significant differences in soil water storage among T1, T2 and T3. The soil water stored within the $40-60 \mathrm{~cm}$ and $60-80 \mathrm{~cm}$ layers showed no significant decrease after sowing (29th April). The results indicated that the soil water consumption at the seedling stage was dominated in the upper soil layer. During this stage, cotton seedling self-transpirations occurred at a low rate, and surface evaporation dominated; therefore, the soil water in CK was mostly concentrated on the surface (Table 1). The soil water stored in the $20-40 \mathrm{~cm}$ and $60-80 \mathrm{~cm}$ layer in 2015 was significantly greater, respectively, than it was in 2014 (Table 1) because of the high precipitation at the seedling stage in 2015 (Fig. 1).

The soil water decreased significantly at the square formation stage (79 DAS, 13 June) (Table 1). The CK treatment showed the lowest soil water storage at the 0-40 and $60-80 \mathrm{~cm}$ layers, whereas the T3 treatment exhibited the highest storage, and a significant difference in soil water stored from the $40-60$ and $60-80 \mathrm{~cm}$ layers was observed between the 2 years. No significant difference between T3 and T2 was observed in 2014; however, the soil water stored in the $0-40$ and $40-60 \mathrm{~cm}$ layers in T3 was significantly higher than it was in $\mathrm{T} 2$ in 2015 . The amount of soil water stored in the $0-20 \mathrm{~cm}$ layers in both seasons and in the 20-40 cm layer in 2015 in CK was significantly less than the amount of water stored in T1, T2 and T3, resulting in less soil water being stored in the 0 $80 \mathrm{~cm}$ soil layer under CK conditions. However, there were no significant differences in the soil water stored within the $40-60 \mathrm{~cm}$ and $60-80 \mathrm{~cm}$ soil layers between CK and each of the other 3 treatments.

The soil water consumption from the seedling stage to the square formation stage (from 28th April to 1st June) 
Table 1 Soil water stored in different soil layers after the sowing, seedling, and square formation stages of cotton in 2014 and 2015 (mm)

\begin{tabular}{|c|c|c|c|c|c|c|c|c|c|c|c|c|c|}
\hline \multirow[t]{2}{*}{ Year } & \multirow[t]{2}{*}{ Treatment } & \multicolumn{4}{|c|}{ After sowing } & \multicolumn{4}{|c|}{ Seedling stage } & \multicolumn{4}{|c|}{ Square formation stage } \\
\hline & & $\begin{array}{l}0 \sim 20 \\
\mathrm{~cm}\end{array}$ & $\begin{array}{l}20 \sim 40 \\
\mathrm{~cm}\end{array}$ & $\begin{array}{l}40 \sim 60 \\
\mathrm{~cm}\end{array}$ & $\begin{array}{l}60 \sim 80 \\
\mathrm{~cm}\end{array}$ & $\begin{array}{l}0 \sim 20 \\
\mathrm{~cm}\end{array}$ & $\begin{array}{l}20 \sim 40 \\
\mathrm{~cm}\end{array}$ & $\begin{array}{l}40 \sim 60 \\
\mathrm{~cm}\end{array}$ & $\begin{array}{l}60 \sim 80 \\
\mathrm{~cm}\end{array}$ & $\begin{array}{l}0 \sim 20 \\
\mathrm{~cm}\end{array}$ & $\begin{array}{l}20 \sim 40 \\
\mathrm{~cm}\end{array}$ & $\begin{array}{l}40 \sim 60 \\
\mathrm{~cm}\end{array}$ & $\begin{array}{l}60 \sim 80 \\
\mathrm{~cm}\end{array}$ \\
\hline \multirow[t]{4}{*}{2014} & CK & $63.0 \mathrm{a}$ & 62.9 a & $55.2 \mathrm{~b}$ & $44.0 \mathrm{~b}$ & $55.8 \mathrm{~b}$ & $54.9 \mathrm{~b}$ & $54.6 \mathrm{~b}$ & $44.3 \mathrm{a}$ & $31.2 \mathrm{~b}$ & $27.9 \mathrm{~b}$ & $37.5 a$ & $37.8 \mathrm{a}$ \\
\hline & $\mathrm{T} 1$ & $60.0 \mathrm{~b}$ & $60.2 \mathrm{ab}$ & $57.4 \mathrm{a}$ & $45.2 \mathrm{~b}$ & $54.5 \mathrm{~b}$ & $57.5 \mathrm{a}$ & $57.1 \mathrm{a}$ & 43.7 a & 38.3 a & $26.9 b$ & 37.7 a & $38.6 \mathrm{a}$ \\
\hline & $\mathrm{T} 2$ & $57.1 \mathrm{~b}$ & $57.2 \mathrm{~b}$ & 58.7 a & $49.5 \mathrm{a}$ & $56.1 \mathrm{ab}$ & $54.8 \mathrm{~b}$ & 56.3 a & $45.4 \mathrm{a}$ & 37.8 a & 36.6 a & 36.7 a & $38.6 \mathrm{a}$ \\
\hline & T3 & $57.8 \mathrm{~b}$ & $57.2 \mathrm{~b}$ & $58.1 \mathrm{a}$ & $51.0 \mathrm{a}$ & $57.3 \mathrm{a}$ & $54.6 \mathrm{~b}$ & $54.7 \mathrm{~b}$ & $47.0 \mathrm{a}$ & 39.2 a & 38.4 a & 36.4 a & $38.6 \mathrm{a}$ \\
\hline \multirow[t]{4}{*}{2015} & CK & $63.1 \mathrm{a}$ & $61.6 \mathrm{a}$ & $56.7 \mathrm{~b}$ & $60.2 \mathrm{~b}$ & $52.1 \mathrm{a}$ & $59.4 \mathrm{~b}$ & $58.5 a$ & $59.0 \mathrm{~b}$ & $27.1 \mathrm{C}$ & $34.8 c$ & $47.5 \mathrm{ab}$ & $54.4 \mathrm{a}$ \\
\hline & $\mathrm{T} 1$ & $59.0 \mathrm{~b}$ & $62.5 \mathrm{a}$ & 62.8 a & $60.7 b$ & $55.1 \mathrm{a}$ & $62.4 \mathrm{a}$ & $58.6 \mathrm{a}$ & $59.5 \mathrm{~b}$ & $33.3 \mathrm{~b}$ & $42.1 \mathrm{~b}$ & 49.9 a & $54.4 \mathrm{a}$ \\
\hline & $\mathrm{T} 2$ & $57.4 \mathrm{~b}$ & $58.0 \mathrm{~b}$ & $63.4 \mathrm{a}$ & $63.6 \mathrm{a}$ & $54.0 \mathrm{a}$ & $57.4 \mathrm{~b}$ & $58.5 a$ & $62.7 \mathrm{a}$ & $31.3 b c$ & $44.0 \mathrm{a}$ & $46.7 \mathrm{~b}$ & $55.1 \mathrm{a}$ \\
\hline & T3 & $57.8 \mathrm{~b}$ & $59.1 \mathrm{~b}$ & $62.6 \mathrm{a}$ & $63.7 \mathrm{a}$ & $56.0 \mathrm{a}$ & $58.1 \mathrm{~b}$ & $58.2 \mathrm{a}$ & $62.5 \mathrm{a}$ & $36.4 \mathrm{a}$ & $45.0 \mathrm{a}$ & $48.0 \mathrm{a}$ & $54.9 \mathrm{a}$ \\
\hline
\end{tabular}

Note: The treatments were as follows: T1 (replacing the topsoil from $0 \sim 15 \mathrm{~cm}$ with the subsoil from $15 \sim 30 \mathrm{~cm}$ ), T2 (replacing the topsoil from $0 \sim 20 \mathrm{~cm}$ with the subsoil from $20 \sim 40 \mathrm{~cm}$ plus subsoiling at the $40 \sim 55 \mathrm{~cm}$ layer), T3 (replacing the topsoil from $0 \sim 20 \mathrm{~cm}$ with the subsoil from $20 \sim 40 \mathrm{~cm}$ plus subsoiling at the $40 \sim 70 \mathrm{~cm}$ layer) and CK (rotary tillage within $15 \mathrm{~cm}$ ). Different lower-case letters indicated significant difference between treatments within the same year

increased significantly $(P=0.0044)$ (Fig. 4), and the soil water consumption was higher in CK than in T1, T2, and T3 because the surface evaporation rate continued to increase with increasing temperature and light intensity. In addition, as the cotton roots grew rapidly, the absorption of soil water increased. Therefore, the soil water stored in the $0-40 \mathrm{~cm}$ layer was higher than that stored in the $40-80 \mathrm{~cm}$ layer. The soil water stored in the $60-80 \mathrm{~cm}$ layer was considerably lower than that in the higher layers.

The soil water that was stored at the initial flowering stage (13th August, 79 DAS) decreased further (Table 2); however, the soil water stored in the different treatments increased with an increase in the soil disturbance depth. The soil water stored in the $0-40 \mathrm{~cm}$ layer at the initial flowering stage showed no significant difference between

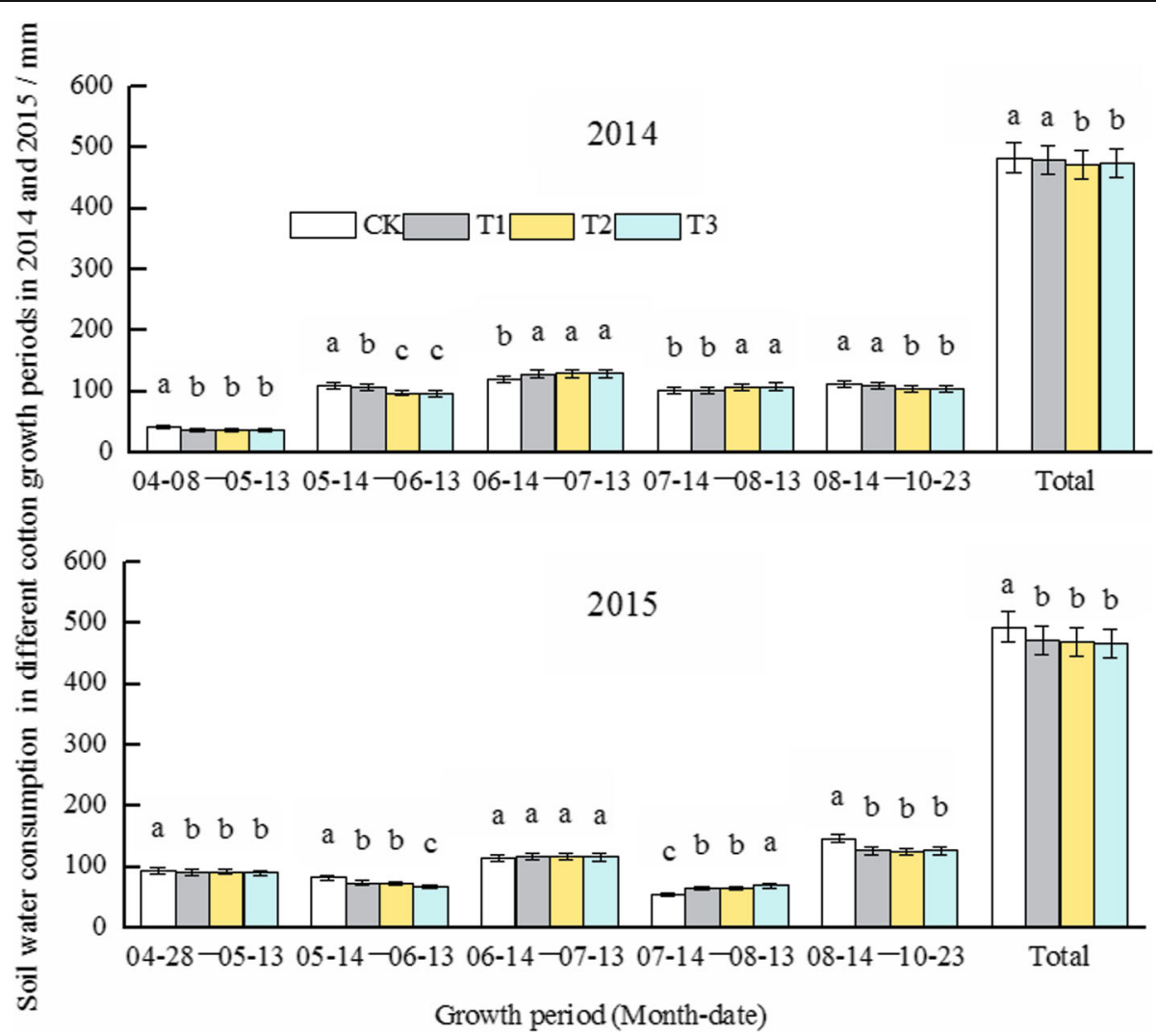

Fig. 4 Changes in soil water consumption during different cotton growth stages in 2014 and 2015 
Table 2 Soil water stored in different soil layers at the initial flowering stage, boll formation stage, and boll opening stage of cotton in 2014 and 2015 (mm)

\begin{tabular}{|c|c|c|c|c|c|c|c|c|c|c|c|c|c|}
\hline \multirow[t]{2}{*}{ Year } & \multirow[t]{2}{*}{ Treatment } & \multicolumn{4}{|c|}{ Initial flowering stage } & \multicolumn{4}{|c|}{ Boll formation stage } & \multicolumn{4}{|c|}{ Boll opening stage } \\
\hline & & $\begin{array}{l}0 \sim 20 \\
\mathrm{~cm}\end{array}$ & $\begin{array}{l}20 \sim 40 \\
\mathrm{~cm}\end{array}$ & $\begin{array}{l}40 \sim 60 \\
\mathrm{~cm}\end{array}$ & $\begin{array}{l}60 \sim 80 \\
\mathrm{~cm}\end{array}$ & $\begin{array}{l}0 \sim 20 \\
\mathrm{~cm}\end{array}$ & $\begin{array}{l}20 \sim 40 \\
\mathrm{~cm}\end{array}$ & $\begin{array}{l}40 \sim 60 \\
\mathrm{~cm}\end{array}$ & $\begin{array}{l}60 \sim 80 \\
\mathrm{~cm}\end{array}$ & $\begin{array}{l}0 \sim 20 \\
\mathrm{~cm}\end{array}$ & $\begin{array}{l}20 \sim 40 \\
\mathrm{~cm}\end{array}$ & $\begin{array}{l}\text { 40 60 } \\
\mathrm{cm}\end{array}$ & $\begin{array}{l}60 \sim 80 \\
\mathrm{~cm}\end{array}$ \\
\hline \multirow[t]{4}{*}{2014} & CK & $23.7 b$ & $29.5 b$ & $38.3 \mathrm{a}$ & $37.2 \mathrm{a}$ & $40.2 \mathrm{~b}$ & $40.9 \mathrm{~b}$ & $45.8 \mathrm{a}$ & $39.5 \mathrm{a}$ & $27.9 \mathrm{~b}$ & $35.3 b$ & $34.6 \mathrm{a}$ & $37.2 b$ \\
\hline & $\mathrm{T} 1$ & $24.7 b$ & $26.9 \mathrm{~b}$ & $40.0 \mathrm{a}$ & $36.6 \mathrm{a}$ & $42.1 \mathrm{a}$ & $41.2 b$ & $45.5 \mathrm{a}$ & $38.1 \mathrm{ab}$ & $27.6 \mathrm{~b}$ & $33.3 b$ & $35.7 \mathrm{a}$ & 39.5 a \\
\hline & $\mathrm{T} 2$ & $28.9 \mathrm{a}$ & $31.2 \mathrm{a}$ & $37.8 \mathrm{a}$ & $37.2 \mathrm{a}$ & $42.6 \mathrm{a}$ & $43.2 \mathrm{a}$ & $43.6 \mathrm{~b}$ & $38.9 \mathrm{ab}$ & $31.7 \mathrm{a}$ & $37.8 \mathrm{a}$ & $34.8 \mathrm{a}$ & 39.9 a \\
\hline & T3 & $30.2 \mathrm{a}$ & $31.9 \mathrm{a}$ & $37.8 \mathrm{a}$ & $36.7 \mathrm{a}$ & $43.5 \mathrm{a}$ & $44.0 \mathrm{a}$ & $42.7 \mathrm{~b}$ & $37.5 b$ & $32.0 \mathrm{a}$ & $38.4 \mathrm{a}$ & $34.5 \mathrm{a}$ & $37.0 \mathrm{~b}$ \\
\hline \multirow[t]{4}{*}{2015} & CK & $23.2 \mathrm{c}$ & $24.6 \mathrm{C}$ & $35.2 \mathrm{~b}$ & $46.5 \mathrm{~b}$ & $68.2 \mathrm{a}$ & $68.0 \mathrm{a}$ & $62.5 \mathrm{~b}$ & $62.6 \mathrm{~b}$ & $26.5 b$ & $28.9 c$ & $38.0 \mathrm{c}$ & $58.7 \mathrm{~b}$ \\
\hline & $\mathrm{T} 1$ & $27.7 b$ & $27.0 \mathrm{~b}$ & $38.4 \mathrm{a}$ & $50.1 \mathrm{a}$ & $65.1 \mathrm{~b}$ & $69.1 \mathrm{a}$ & $64.5 \mathrm{ab}$ & $65.5 \mathrm{ab}$ & $33.0 \mathrm{a}$ & $36.4 \mathrm{ab}$ & $48.1 \mathrm{a}$ & $58.0 \mathrm{~b}$ \\
\hline & $\mathrm{T} 2$ & $26.5 b$ & $25.1 \mathrm{bc}$ & $39.1 \mathrm{a}$ & $50.2 \mathrm{a}$ & $63.2 \mathrm{~b}$ & $66.0 \mathrm{~b}$ & $66.3 \mathrm{a}$ & $66.7 \mathrm{a}$ & $34.7 \mathrm{a}$ & $34.8 b$ & $44.4 \mathrm{~b}$ & $61.2 \mathrm{a}$ \\
\hline & T3 & $32.5 \mathrm{a}$ & $30.0 \mathrm{a}$ & $37.8 \mathrm{a}$ & $49.1 \mathrm{a}$ & $66.1 \mathrm{ab}$ & $65.3 b$ & $66.7 \mathrm{a}$ & $67.5 \mathrm{a}$ & $35.3 \mathrm{a}$ & $38.1 \mathrm{a}$ & $45.2 \mathrm{~b}$ & $62.2 \mathrm{a}$ \\
\hline
\end{tabular}

Note: The treatments were as follows: $T 1$ (replacing the topsoil from $0 \sim 15 \mathrm{~cm}$ with the subsoil from $15 \sim 30 \mathrm{~cm}$ ), $T 2$ (replacing the topsoil from $0 \sim 20 \mathrm{~cm}$ with the subsoil from $20 \sim 40 \mathrm{~cm}$ plus subsoiling at the $40 \sim 55 \mathrm{~cm}$ layer), T3 (replacing the topsoil from $0 \sim 20 \mathrm{~cm}$ with the subsoil from $20 \sim 40 \mathrm{~cm}$ plus subsoiling at the $40 \sim 70 \mathrm{~cm}$ layer) and CK (rotary tillage within $15 \mathrm{~cm}$ ). Different lower-case letters indicated significant difference between treatments within the same year

T2 and T3 in 2014 but did show a significant difference in 2015; however, the soil water stored in the $0-40 \mathrm{~cm}$ layer at the initial flowering stage in T2 and T3 was significantly higher than that in T1 and CK. The soil water stored from 0 to $80 \mathrm{~cm}$ in T3 in 2015 was the highest among the 4 treatments, and the difference in soil water in the $0-80 \mathrm{~cm}$ layer between $\mathrm{T} 1$ and $\mathrm{T} 2$ was not significant, but it was significantly higher than that of CK. The soil water stored in the $0-20 \mathrm{~cm}$ and $20-40 \mathrm{~cm}$ layers in T2 and T3 in 2014 was significantly higher than it was in CK. The soil water stored within the $0-80 \mathrm{~cm}$ soil layers of T1, T2, and T3 in 2015 was significantly higher than it was in CK. The results indicated that during a drought at the initial flowering stage (13th August, 79 DAS), soil replacement plus subsoiling treatments could still help to store more soil water. The soil water consumption in the soil replacement plus subsoiling treatments during this stage was significantly higher than that in CK in 2014; however, no significant difference was found among the treatments in 2015. However, the water consumption in CK was greater than that in soil replacement plus subsoiling treatment from the seedling stage to the budding stage (from 28th April to 1st June) (Fig. 4). In accordance with the law of water consumption, the soil water loss was partly attributed to the transpiration of cotton plants and the gradual sealing of a ridge in the cotton field; the evaporation of surface water declined rapidly after the budding stage. The increase in the water consumption of the cotton in soil replacement plus subsoiling indicated an increase in cotton plant transpiration, which was caused by the abundant supply of soil water and the accelerated growth of cotton.

No significant difference in the soil water stored at the boll formation stage (13th August, 110 DAS) was found among treatments (Table 2), but significant differences in the soil water stored among different soil layers were found. Less rainfall was observed during the boll formation stage in 2014; thus, the soil water stored within the $0-20 \mathrm{~cm}$ layer in the soil replacement plus subsoiling treatments was significantly greater than that in CK (T3 > T2 > T1). The soil water stored from 20 to $40 \mathrm{~cm}$ in T3 and T2 was significantly greater than that in T1 and CK. However, the soil water stored below $40 \mathrm{~cm}$ following soil replacement plus subsoiling was less than that of CK, and the soil water consumption of T2 and T3 was significantly greater than that of CK. This result indicated that during a drought, the soil water in the deep tilth layers in soil replacement plus subsoiling could move upward and then be used fully by the cotton plant. During the boll formation stage (from 14th July to 1st August) in 2015 after irrigation was conducted once, two heavy rainfall events were recorded (Fig. 1), which provided cotton with abundant water for growth. The dynamics of the soil water stored within different soil layers were the same as that after sowing. After soil replacement plus subsoiling, the soil water moved downward and accumulated in the lower soil layer, whereas the soil water in CK accumulated in the upper soil layer because of the plough pan.

The data on the soil water stored in the different soil layers in 2014 and 2015 showed that soil replacement plus subsoiling exerted a strong effect in terms of regulating the soil water. During the dry season, the soil water stored within the deep layers could move upwards for use by the cotton, whereas during the rainy season, the soil water could accumulate in the deep soil layers. In addition, the soil water consumption in the soil replacement plus subsoiling treatments was greater than that for CK from 14th July to 1st August (Fig. 4), indicating that soil replacement plus subsoiling improved the soil water supply for cotton plants and their growth. 
The soil water stored at the boll opening stage (13th October) in the soil replacement plus subsoiling treatments was greater than it was in CK. The amount of soil water stored in T2 and T3 were significantly greater than those obtained in CK and T1 in 2014, whereas the soil water in T3 was the highest in 2015. The soil water of the T2 and T1 treatments showed no significant difference but were significantly higher than that in the CK treatment. The soil water stored in different soil layers was lower in CK than it was after soil replacement plus subsoiling (Table 2). The water consumption in CK during the boll opening stage was the highest among all the treatments, and the water consumption during the boll opening stage in T2 and T3 was significantly lower in 2014 than in 2015. The water consumption exhibited no significant differences among T1, T2 and T3 in 2015 but was significantly lower in soil replacement plus subsoiling treatments compared with that in CK (Fig. 4). At the late boll opening stage, the leaves of the cotton plants fell off, and soil water loss occurred, which was mostly attributed to evaporation. Therefore, the soil water consumption in CK exceeded that of the soil replacement plus subsoiling treatments.

The soil water consumption of cotton plants over the entire growth stage in the T1, T2, and T3 treatments decreased by $3.3,11.4$, and $7.9 \mathrm{~mm}$ in 2014, respectively, relative to that of CK. The soil water consumption levels of $\mathrm{CK}$ and $\mathrm{T} 1$ showed no significant difference but were significantly higher than those of the T2 and T3 treatments. In 2015, the soil water consumption of cotton plants in T1, T2, and T3 over the entire growth stage decreased by 20.0, 22.2, and $27.0 \mathrm{~mm}$ relative to the values obtained in CK, which were significantly higher than those of the T1, T2, and T3 treatments (Fig. 4).

\section{Vertical distribution of soil nutrient properties}

The soil total N (Fig. 5), available P (Fig. 6), and available $\mathrm{K}$ content (Fig. 7) in CK were primarily concentrated within the $0-20 \mathrm{~cm}$ soil layer. With increases in the depth of the soil, the soil nutrient content decreased rapidly. The soil nutrient contents within the $0-20 \mathrm{~cm}$ layer in the 3 soil replacement plus subsoiling treatments were significantly lower than those in CK. On the other hand, the nutrient content from 20 to $40 \mathrm{~cm}$ was higher than that in CK. The total N, available P, and available $\mathrm{K}$ content from 20 to $40 \mathrm{~cm}$ in $\mathrm{T} 2$ and $\mathrm{T} 3$ were significantly higher than those obtained in CK. No significant difference in the total nitrogen below the $40 \mathrm{~cm}$ soil layer was found among all treatments. The available $\mathrm{P}$ and available $\mathrm{K}$ below the $40 \mathrm{~cm}$ layer were still increased to a certain extent relative to that of CK. According to the results above, T2 and T3 showed increased nutrient content in the deep soil layer; thus, the vertical distribution of nutrients in the soil layer was more balanced.

\section{Effects of soil replacement plus subsoiling on the growth and development of cotton Cotton root growth and distribution}

Soil replacement plus subsoiling significantly promoted the root growth of cotton in different soil layers in both years (Figs. 8 and 9). Compared with CK, the root lengths of $\mathrm{T} 1, \mathrm{~T} 2$, and $\mathrm{T} 3$ increased by 14.3, 19.3, and

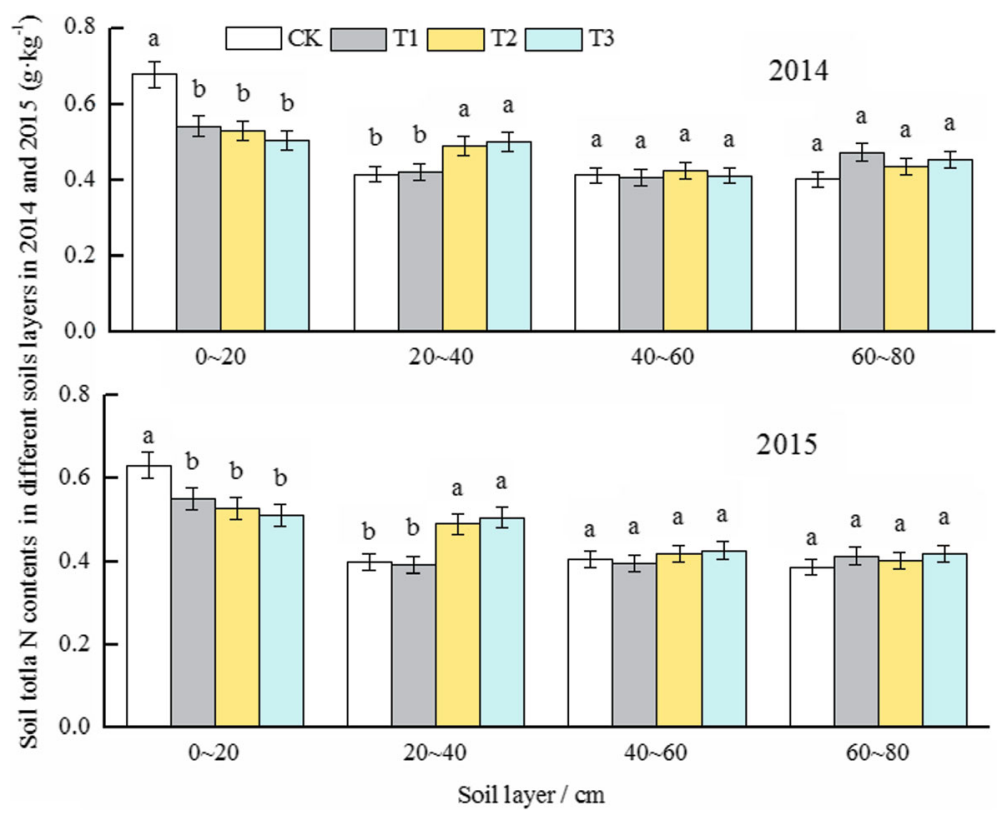

Fig. 5 Changes in total soil N contents in different soil layers in different treatments in 2014 and 2015 


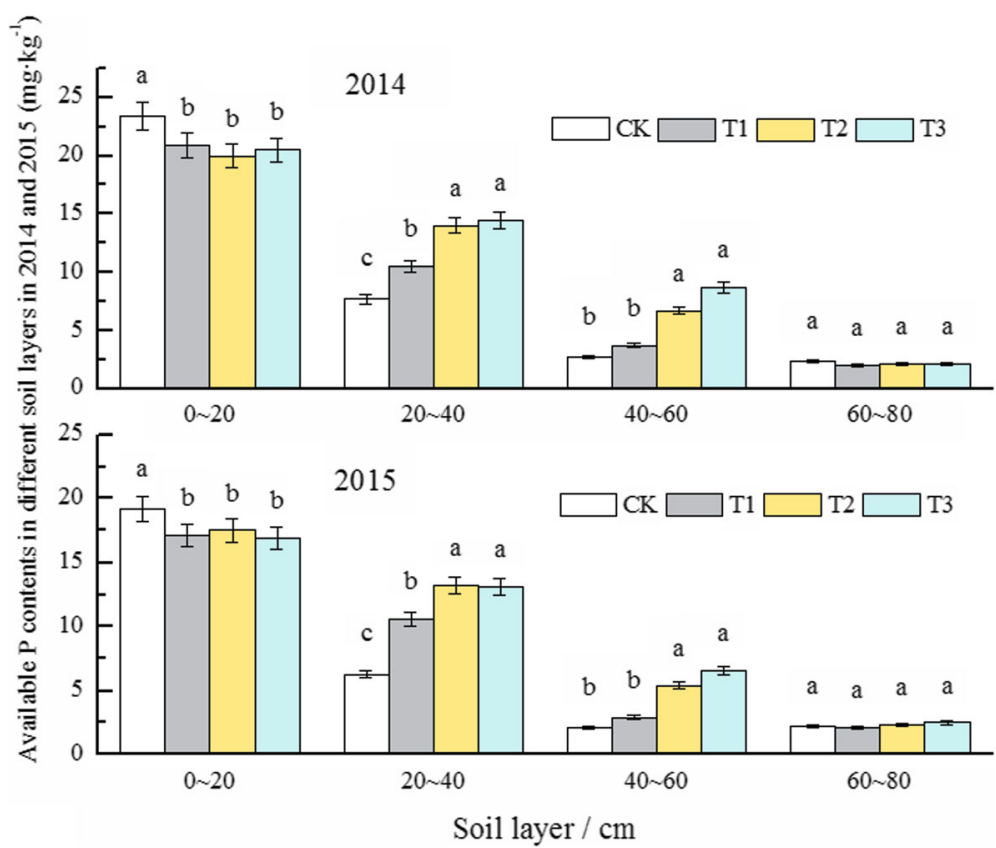

Fig. 6 Changes in available soil P contents in different soil layers in different treatments in 2014 and 2015

$26.4 \%$, respectively, in 2014 and increased by $11.0,26.4$, and $43.3 \%$, respectively, in 2015 . The total root length, root dry weight, root surface area, and root volume of cotton within the $0-60 \mathrm{~cm}$ layer of the soil replacement plus the subsoiling treatments for both years increased significantly compared with those parameters for CK.

The treatments were as follows: T1 (replacing the topsoil from 0 to $15 \mathrm{~cm}$ with the subsoil from 15 to $30 \mathrm{~cm}$ ),
T2 (replacing the topsoil from 0 to $20 \mathrm{~cm}$ with the subsoil from 20 to $40 \mathrm{~cm}$ plus subsoiling at the $40-55 \mathrm{~cm}$ layer), T3 (replacing the topsoil from 0 to $20 \mathrm{~cm}$ with the subsoil from 20 to $40 \mathrm{~cm}$ plus subsoiling at the 40 $70 \mathrm{~cm}$ layer) and CK (rotary tillage within $15 \mathrm{~cm}$ ). A, B, $\mathrm{C}$, and $\mathrm{D}$ represent the cotton root length, cotton root surface area, cotton root volume and cotton root dry weight, respectively. Different lowercase letters indicate

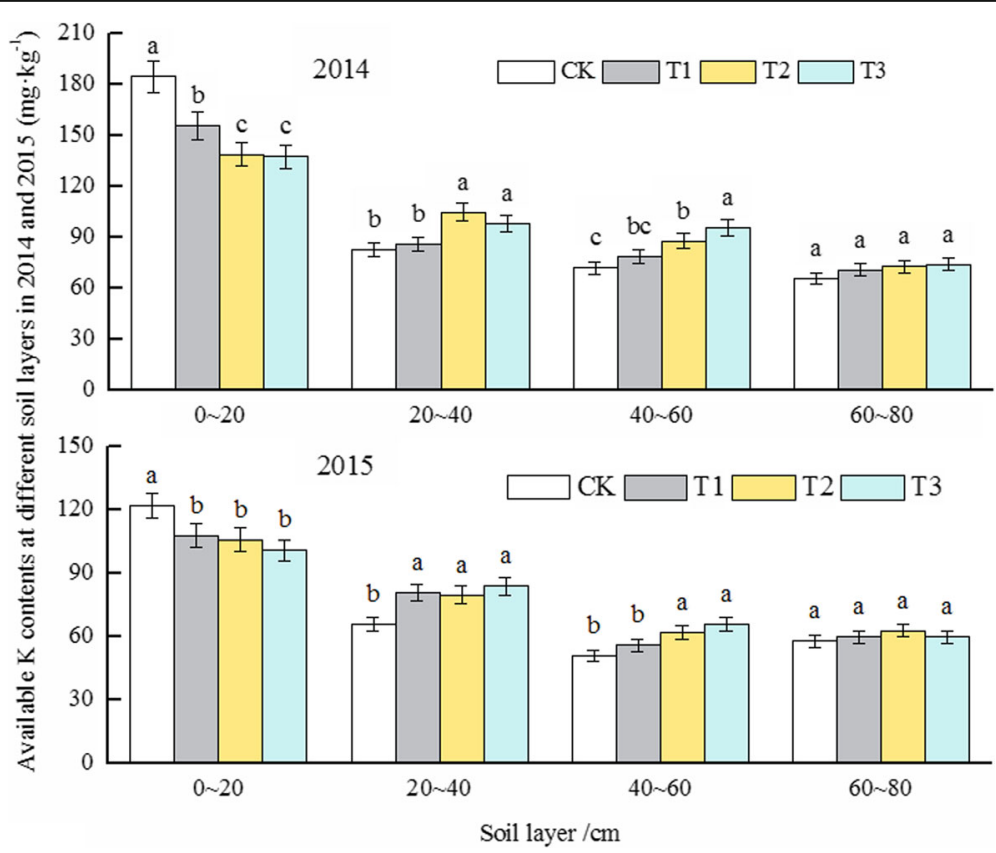

Fig. 7 Changes in available soil K contents in different soil layers in different treatments in 2014 and 2015 


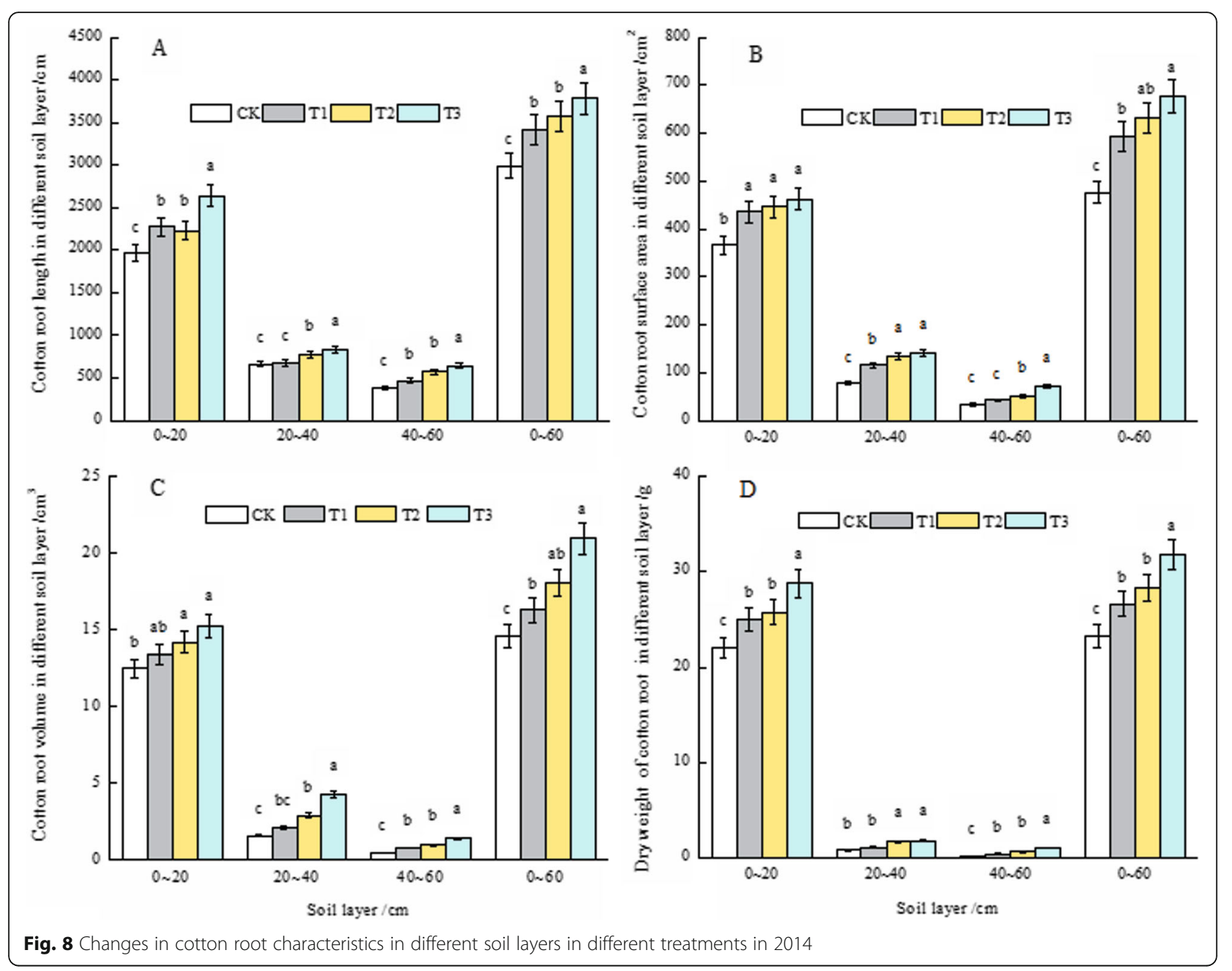

significant differences between treatments within the same year.

\section{Aboveground dry matter accumulation of cotton}

The dry matter accumulation of cotton in the soil replacement plus subsoiling treatments was lower during the seedling and budding stages and higher during the boll formation stage and boll opening stage relative to that in CK (Table 3). The dry matter accumulation of cotton in the soil replacement plus subsoiling treatments at the seedling and budding stages was significantly lower than that obtained in CK. There were significant differences in the stems and leaves of cotton in 2014 and the squares and bolls of cotton in 2015 between the soil replacement plus subsoiling treatments and CK at the initial flowering stage. At the full boll-setting stage, the dry matter accumulation in T2 and T3 was significantly higher than that it was for CK and T1. At the boll opening stage, the dry matter accumulation in T1, T2, and T3 increased significantly, by $10.6,24.1$, and $30.0 \%$, respectively, relative to the accumulation observed in CK in 2014 , and it increased significantly, by $16.8,25.8$, and $42.9 \%$, respectively, in 2015 . Despite the drought that occurred during the flowering and boll-setting stages in 2014, the cotton plants in T2 and T3 grew steadily, and no difference in dry matter accumulation between the years was determined. In 2015, irrigation provided once during the flowering and boll-setting stages in combination with the occurrence of 2 large rainfall events resulted in the vigorous growth of cotton in T3. The dry matter accumulation in the stems and leaves was significantly higher than it was in the other treatments. The results showed that soil replacement plus subsoiling did not promote cotton growth in the early growth stages but substantially contributed to its growth at later growth stages.

\section{Yield and yield components}

Soil replacement plus subsoiling significantly increased the number of cotton bolls per plant, the boll weight, and the lint yield (Table 4). The number of bolls per plant in the 3 soil replacement plus subsoiling 


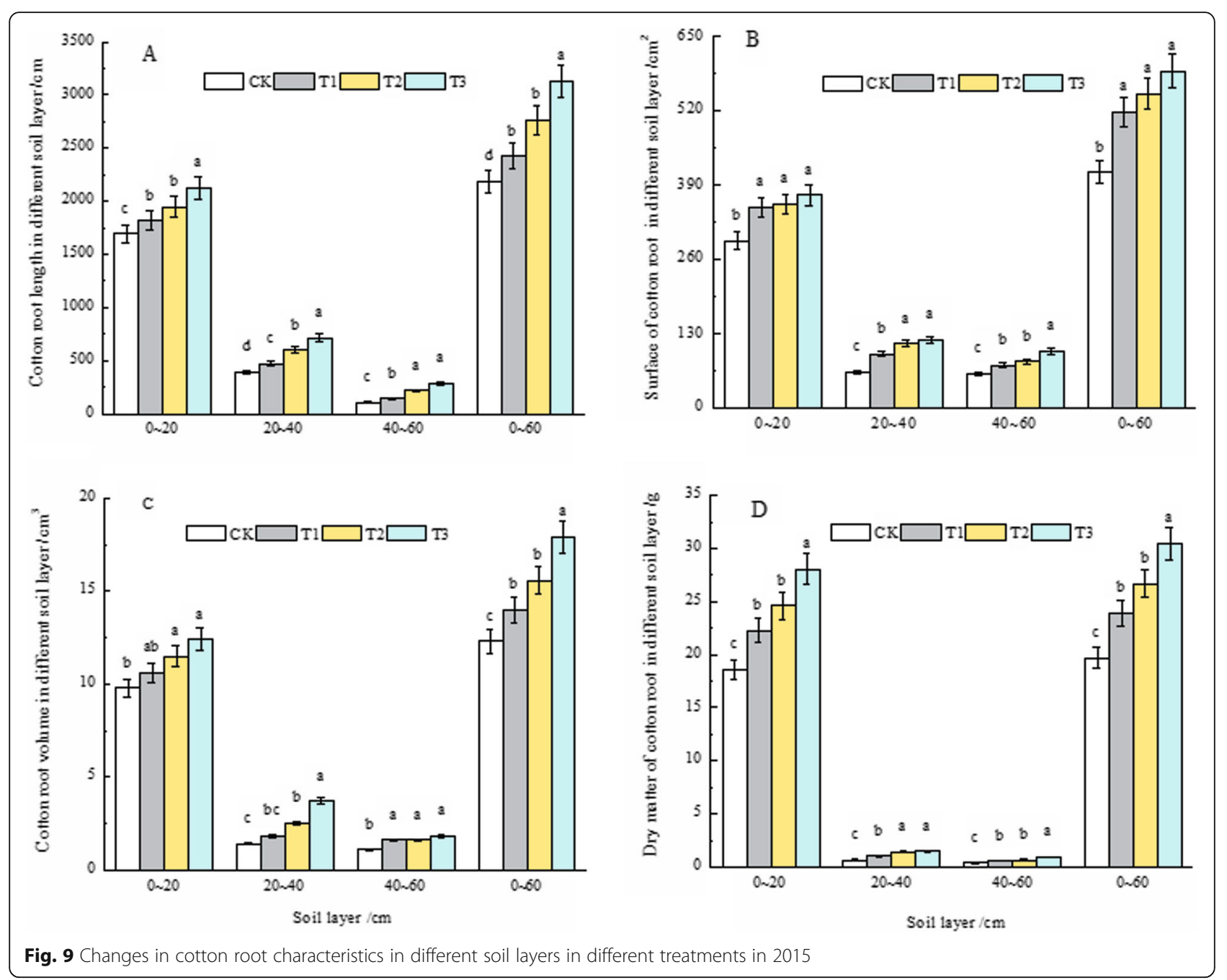

Table 3 Dry matter accumulation of above-ground cotton at different growth stages in different treatments (g.plant ${ }^{-1}$ )

\begin{tabular}{|c|c|c|c|c|c|c|c|c|c|}
\hline \multirow[t]{2}{*}{ Year } & \multirow[t]{2}{*}{ Treatment } & \multirow{2}{*}{$\begin{array}{l}\text { Seedling } \\
\text { stage }\end{array}$} & \multirow{2}{*}{$\begin{array}{l}\text { Square } \\
\text { formation } \\
\text { stage }\end{array}$} & \multicolumn{2}{|c|}{ Initial bloom stage } & \multicolumn{2}{|c|}{ Boll formation stage } & \multicolumn{2}{|c|}{ Boll opening stage } \\
\hline & & & & Stem and leaf & Square and boll & Stem and leaf & Square and boll & Stem and leaf & Square and boll \\
\hline \multirow[t]{4}{*}{2014} & CK & $0.95 \mathrm{a}$ & $5.4 \mathrm{a}$ & $35.9 \mathrm{C}$ & $10.8 \mathrm{a}$ & $79.9 \mathrm{~b}$ & $65.5 \mathrm{~b}$ & $59.7 c$ & $116.9 \mathrm{C}$ \\
\hline & $\mathrm{T} 1$ & $0.83 b$ & $4.9 \mathrm{~b}$ & $38.2 b$ & $9.0 \mathrm{a}$ & $85.7 \mathrm{~b}$ & $71.2 \mathrm{a}$ & $66.0 \mathrm{~b}$ & $129.3 b$ \\
\hline & $\mathrm{T} 2$ & $0.71 \mathrm{c}$ & $4.9 \mathrm{~b}$ & $40.6 \mathrm{ab}$ & $4.5 \mathrm{~b}$ & $96.7 \mathrm{a}$ & $75.7 \mathrm{a}$ & $74.1 \mathrm{a}$ & $145.0 \mathrm{a}$ \\
\hline & T3 & $0.72 \mathrm{c}$ & $4.8 \mathrm{~b}$ & $43.1 \mathrm{a}$ & $5.2 b$ & $97.9 \mathrm{a}$ & $72.6 \mathrm{a}$ & $77.6 \mathrm{a}$ & $151.9 \mathrm{a}$ \\
\hline \multirow[t]{4}{*}{2015} & CK & $0.92 \mathrm{a}$ & $4.8 \mathrm{a}$ & $45.5 \mathrm{~b}$ & $12.4 \mathrm{a}$ & $75.4 \mathrm{C}$ & $61.8 \mathrm{a}$ & $52.9 \mathrm{C}$ & $103.5 \mathrm{C}$ \\
\hline & $\mathrm{T} 1$ & $0.83 b$ & $4.4 \mathrm{~b}$ & $47.9 \mathrm{~b}$ & $7.7 \mathrm{~b}$ & $82.5 \mathrm{c}$ & $63.8 \mathrm{a}$ & $61.8 \mathrm{~b}$ & $120.9 \mathrm{~b}$ \\
\hline & $\mathrm{T} 2$ & $0.75 c$ & $4.1 \mathrm{~b}$ & $52.5 \mathrm{a}$ & $5.8 \mathrm{~b}$ & $92.6 \mathrm{~b}$ & $63.2 \mathrm{a}$ & $74.5 \mathrm{~b}$ & $130.3 \mathrm{a}$ \\
\hline & $\mathrm{T} 3$ & $0.73 c$ & $4.0 \mathrm{~b}$ & $54.1 \mathrm{a}$ & $6.0 \mathrm{~b}$ & $102.7 \mathrm{a}$ & $60.1 \mathrm{a}$ & $85.5 \mathrm{a}$ & $115.0 \mathrm{~b}$ \\
\hline
\end{tabular}

Note: The treatments were as follows: T1 (replacing the topsoil from $0 \sim 15 \mathrm{~cm}$ with the subsoil from $15 \sim 30 \mathrm{~cm}$ ), T2 (replacing the topsoil from $0 \sim 20 \mathrm{~cm}$ with the subsoil from $20 \sim 40 \mathrm{~cm}$ plus subsoiling at the $40 \sim 55 \mathrm{~cm}$ layer), T3 (replacing the topsoil from $0 \sim 20 \mathrm{~cm}$ with the subsoil from $20 \sim 40 \mathrm{~cm}$ plus subsoiling at the $40 \sim 70 \mathrm{~cm}$ layer) and CK (rotary tillage within $15 \mathrm{~cm}$ ). Different lower-case letters indicated significant difference between treatments within the same year 
Table 4 Cotton yield and yield components in different treatments in 2014 and 2015

\begin{tabular}{|c|c|c|c|c|c|}
\hline$\overline{\text { Year }}$ & Treatment & Number of bolls per $\mathrm{m}^{2}$ & Boll weight/g & Lint percentage $/ \%$ & Lint yield $/\left(\mathrm{kg} \cdot \mathrm{ha}^{-1}\right)$ \\
\hline \multirow[t]{4}{*}{2014} & CK & $93.7 \mathrm{~b}$ & $5.2 \mathrm{~b}$ & $40.9 \mathrm{a}$ & $1693 \mathrm{~b}$ \\
\hline & $\mathrm{T} 1$ & $100.0 \mathrm{a}$ & $5.3 b$ & $38.6 b$ & $1732 b$ \\
\hline & $\mathrm{T} 2$ & $101.7 \mathrm{a}$ & $5.5 \mathrm{a}$ & $38.5 b$ & $1797 a$ \\
\hline & $\mathrm{T} 3$ & $102.3 \mathrm{a}$ & $5.5 \mathrm{a}$ & $39.1 \mathrm{~b}$ & 1829 a \\
\hline \multirow[t]{4}{*}{2015} & CK & $73.7 c$ & $5.6 \mathrm{~b}$ & $39.1 \mathrm{a}$ & $1549 c$ \\
\hline & $\mathrm{T} 1$ & $77.7 \mathrm{~b}$ & $5.8 \mathrm{a}$ & $38.1 \mathrm{a}$ & $1648 \mathrm{~b}$ \\
\hline & $\mathrm{T} 2$ & $79.4 \mathrm{a}$ & $5.8 \mathrm{a}$ & $38.6 \mathrm{a}$ & $1706 a$ \\
\hline & $\mathrm{T} 3$ & $76.6 \mathrm{~b}$ & $5.8 \mathrm{a}$ & $38.2 \mathrm{a}$ & $1628 \mathrm{~b}$ \\
\hline
\end{tabular}

Note: The treatments were as follows: T1 (replacing the topsoil from $0 \sim 15 \mathrm{~cm}$ with the subsoil from $15 \sim 30 \mathrm{~cm}$ ), T2 (replacing the topsoil from $0 \sim 20 \mathrm{~cm}$ with the subsoil from $20 \sim 40 \mathrm{~cm}$ plus subsoiling at the $40 \sim 55 \mathrm{~cm}$ layer), T3 (replacing the topsoil from $0 \sim 20 \mathrm{~cm}$ with the subsoil from $20 \sim 40 \mathrm{~cm}$ plus subsoiling at the $40 \sim 70 \mathrm{~cm}$ layer) and CK (rotary tillage within $15 \mathrm{~cm}$ ). Different lower-case letters indicated significant difference between treatments within the same year

treatments was significantly greater than that in CK in both years. In 2014, the lint percentages in the 3 soil replacement plus subsoiling treatments were lower than those in CK, and the lint yields in the T1, T2 and T3 treatments increased by $2.3,6.1$, and $8.0 \%$, respectively, relative to that obtained in CK. In 2015, the boll weights in the 3 soil replacement plus subsoiling treatments were significantly higher than those obtained in CK; however, no significant differences were found among the lint percentages for all treatments, and the lint yield in the $\mathrm{T} 1, \mathrm{~T} 2$ and $\mathrm{T} 3$ treatments increased by $6.4,10.2$, and $5.1 \%$, respectively, relative to that obtained in CK.

As shown in Table 5, cotton root length in the 20-60 $\mathrm{cm}$ soil layer, dry matter accumulation of aboveground plant and lint yield were positively correlated with soil total $\mathrm{N}$, available $\mathrm{P}$, and available $\mathrm{K}$ content in different soil layers in 2014 and 2015. The regression equation between cotton root length in the $20-60 \mathrm{~cm}$ soil layer

Table 5 Relationship of cotton root length in the $20 \sim 60 \mathrm{~cm}$ soil layer, dry matter accumulation of above-ground cotton at the boll opening stage and cotton lint yield to soil total N, available P, available K content in different soil layers in 2014 and 2015

\begin{tabular}{|c|c|c|c|c|c|}
\hline \multirow[t]{2}{*}{ Dependent Variable (Units) } & \multirow[t]{2}{*}{ Year } & \multirow{2}{*}{$\begin{array}{l}\text { Soil } \\
\text { layer } \\
(\mathrm{cm})\end{array}$} & \multicolumn{3}{|c|}{ Regression equation and coefficient of determination $\left(R^{2}\right)$} \\
\hline & & & $\begin{array}{l}\text { Soil total } N \text { content } \\
\left(\mathrm{g} \mathrm{kg}^{-1}\right)\end{array}$ & $\begin{array}{l}\text { Soi I available P content } \\
\left(\mathrm{mg} \mathrm{kg}^{-1}\right)\end{array}$ & $\begin{array}{l}\text { Soil available } \mathrm{K} \text { content } \\
\left(\mathrm{mg} \mathrm{kg}^{-1}\right)\end{array}$ \\
\hline \multirow[t]{6}{*}{ Root length in 20 60 cm soil layer $(\mathrm{cm})$} & \multirow[t]{3}{*}{2014} & $0 \sim 20$ & $-2149.5 x+2457.8(0.7266)$ & $-104.0 x+3450.4(0.6411)$ & $-8.2 x+2515.9(0.8439)$ \\
\hline & & $20 \sim 40$ & $4203.5 x-676.1\left(0.9269^{*}\right)$ & $60.1 x+545.7\left(0.9373^{*}\right)$ & $16.0 x-246.6(0.7079)$ \\
\hline & & $40 \sim 60$ & $8076.1 x-2101.6(0.111)$ & $71.0 x+859.1\left(0.9911^{*}\right)$ & $18.7 x-322.5\left(0.9968^{*}\right)$ \\
\hline & \multirow[t]{3}{*}{2015} & $0 \sim 20$ & $-3772.1 x+2825.1(0.7949)$ & $-157.4 x+3511.1(0.5383)$ & $-22.2 x+3152.7(0.7895)$ \\
\hline & & $20 \sim 40$ & $3495.4 x-830.0(0.8777)$ & $61.2 x+68.9(0.7760)$ & $22.2 x-996.6(0.6283)$ \\
\hline & & $40 \sim 60$ & $13797.0 x-4947.7(0.7162)$ & $105.8 x+280.1\left(0.9838^{*}\right)$ & $33.7 x-1250.8\left(0.9825^{*}\right)$ \\
\hline \multirow{6}{*}{$\begin{array}{l}\text { Dry matter accumulation of above ground } \\
\text { cotton at boll opening stage ( } \mathrm{g} \mathrm{plant}^{-1} \text { ) }\end{array}$} & \multirow[t]{3}{*}{2014} & $0 \sim 20$ & $-273.9 x+359.5(0.8031)$ & $-13.7 x+494.5(0.7520)$ & $-1.04 x+365.9\left(0.9204^{*}\right)$ \\
\hline & & $20 \sim 40$ & $506.0 x-26.3\left(0.9143^{*}\right)$ & $7.5 x+118.2\left(0.9824^{*}\right)$ & $2.0 x+16.9(0.7664)$ \\
\hline & & $40 \sim 60$ & $1097.7 x-249.9(0.1397)$ & $8.5 x+159.1\left(0.9560^{*}\right)$ & $2.3 x+16.7\left(0.9796^{*}\right)$ \\
\hline & \multirow[t]{3}{*}{2015} & $0 \sim 20$ & $-400.7 x+408.7\left(0.9351^{*}\right)$ & $-17.6 x+496.7(0.6998)$ & $-2.28 x+435.4(0.8715)$ \\
\hline & & $20 \sim 40$ & $303.7 x+50.6(0.6907)$ & $6.8 x+112.9\left(0.9916^{*}\right)$ & $2.4 x-3.5(0.7900)$ \\
\hline & & $40 \sim 60$ & $999.1 x-225.0(0.3915)$ & $9.3 x+146.5(0.7948)$ & $3.1 x+4.3(0.8635)$ \\
\hline \multirow[t]{6}{*}{ cotton lint yield $\left(\mathrm{kg} \mathrm{ha}^{-1}\right)$} & \multirow[t]{3}{*}{2014} & $0 \sim 20$ & $-684.1 x+2148.4(0.7486)$ & $-33.8 x+2478.81(0.6881)$ & $-2.6 x+2168.7(0.8775)$ \\
\hline & & $20 \sim 40$ & $1325.8 x+1156.5\left(0.9380^{*}\right)$ & $19.1 x+1540.1\left(0.9639^{*}\right)$ & $5.2 x+1278.7(0.7574)$ \\
\hline & & $40 \sim 60$ & $2860.4 x+577.1(0.1417)$ & $22.1 x+1642.1\left(0.9808^{*}\right)$ & $5.8 x+1272.9\left(0.9888^{*}\right)$ \\
\hline & \multirow[t]{3}{*}{2015} & $0 \sim 20$ & $-968.1 x+2170.5(0.6267)$ & $-44.3 x+2415.7(0.5106)$ & $-5.3 x+2211.4(0.5390)$ \\
\hline & & $20 \sim 40$ & $563.2 x+1381.4(0.2728)$ & $17.2 x+1447.1(0.7329)$ & $6.1 x+1161.3(0.5609)$ \\
\hline & & $40 \sim 60$ & $1211.8 x+1134.1(0.0661)$ & $17.5 x+1558.4(0.3221)$ & $6.2 x+1268.5(0.3979)$ \\
\hline
\end{tabular}


and soil total $\mathrm{N}$, available $\mathrm{P}$ content in the $20-40 \mathrm{~cm}$ soil layer in 2014, and soil available $\mathrm{K}$ content in the 40-60 $\mathrm{cm}$ soil layer in 2014 and 2015 was significant. The regression equation between dry matter accumulation of aboveground cotton and soil total $\mathrm{N}$ content in the 20$40 \mathrm{~cm}$ soil layer, soil available P content in the $20-60 \mathrm{~cm}$ soil layer, soil $\mathrm{K}$ content in the $0-20 \mathrm{~cm}$ and $40-60 \mathrm{~cm}$ soil layer in 2014, soil total $\mathrm{N}$ content in the $20-40 \mathrm{~cm}$ soil layer and soil available P content in the $20-40 \mathrm{~cm}$ soil layer in 2015 was significant. The regression equation between cotton lint yield and soil total $\mathrm{N}$ content in the $20-40 \mathrm{~cm}$ soil layer, soil available $\mathrm{P}$ content in the $20-60 \mathrm{~cm}$ soil layer, and soil available $\mathrm{K}$ content in the $40-60 \mathrm{~cm}$ soil layer in 2014 was significant. Soil replacement plus subsoiling treatments increased the soil total $\mathrm{N}$ content in the $20-40 \mathrm{~cm}$ soil layer and the soil available $P$ and available $K$ contents in the $20-60 \mathrm{~cm}$ soil layer compared with those in the CK treatment, thereby improving the growth of cotton roots and the dry matter accumulation of aboveground plant and increasing the lint yield.

\section{Effects of soil replacement plus subsoiling on weeds, diseases, and the premature senescence of cotton}

The effect of soil replacement plus subsoiling on weed control in the cotton field was apparent (Table 6), and the effects of T1, T2, and T3 on weed control in the cotton field were similar. The number of weeds observed in the cotton field under the soil replacement plus subsoiling treatments was less than that observed in CK.

Soil replacement plus subsoiling significantly reduced the DPI of the cotton (Fig. 10). In 2014, the DPI of cotton in CK reached $76.3 \%$, which was significantly higher than that in the 3 soil replacement plus subsoiling treatments, and the DPI of cotton in T1 was significantly higher than those in T2 and T3. No significant difference was determined between T2 and T3. The DPI of cotton in 2015 was lower than it was in 2014, but the change trend among the different treatments was the same. At the late growth stages, cotton diseases and leaf senescence rarely occurred in the soil replacement plus subsoiling treatments, which effectively released some serious pressure of diseases and leaf senescence in successive cotton fields.

\section{Discussion}

Effects of soil replacement plus subsoiling on the physical and chemical properties of the soil

Farmland with good soil tilth can, in combination with the appropriate soil moisture and nutrient status, provide a good foundation for high-yielding soil. Suitable tillage practices help to establish good tilth layers, improve the soil structure, and provide a suitable soil ecological environment for crop growth and yield formation.

Traditional deep tillage and subsoiling play a role in breaking the plough pan and reducing the soil bulk density (Wang et al. 2006), which can increase the capacity for soil water storage (Tangyuan et al. 2009), reduce surface evaporation, improve water use efficiency, and reduce yield losses caused by droughts (Schneider et al. 2017). However, the depth of deep tillage and subsoiling generally ranges from $25 \mathrm{~cm}$ to $35 \mathrm{~cm}$ (Jin et al. 2007; Motavalli et al. 2003). Singh et al. (2019a, 2019b) reported that subsoiling exerted a beneficial effect on soil physical properties by reducing the bulk density and improving the infiltration rate, and any subsoiling at 1.0 or $1.5 \mathrm{~m}$ once in 3 years has the potential to improve the productivity of cotton-wheat cropping systems.

In the current study, after the plough layer was completely broken and the tilth layers were rebuilt, the soil bulk density at the $0-60 \mathrm{~cm}$ soil layer decreased significantly. This reduction contributed to soil water conduction. After irrigation or heavy rain, the soil water could percolate to the deeper soil layer, which reduced the evaporation from the soil surface and preserved soil moisture. In contrast, the rotary tillage treatment accumulated more water within the upper soil layer, and the soil water consumption at the early part of the growth stage was

Table 6 Changes in weeds weight at different cotton growth stages in different treatments in 2014 and $2015\left(\mathrm{~g} \cdot \mathrm{m}^{-2}\right)$

\begin{tabular}{lllll}
\hline Year & Treatment & Seedling stage & Initial bloom stage & Boll opening stage \\
\hline 2014 & CK & $9.7 \mathrm{a}$ & $16.9 \mathrm{a}$ & $66.8 \mathrm{a}$ \\
& T1 & $0.5 \mathrm{~b}$ & $1.2 \mathrm{~b}$ & $0.5 \mathrm{~b}$ \\
& T2 & $0.8 \mathrm{~b}$ & $0.5 \mathrm{~b}$ & $0.4 \mathrm{~b}$ \\
& T3 & $0.2 \mathrm{~b}$ & $2.0 \mathrm{~b}$ & $1.8 \mathrm{~b}$ \\
& CK & $10.4 \mathrm{a}$ & $15.9 \mathrm{a}$ & $81.7 \mathrm{a}$ \\
& T1 & $0.8 \mathrm{~b}$ & $1.7 \mathrm{~b}$ & $0.9 \mathrm{~b}$ \\
& T2 & $1.2 \mathrm{~b}$ & $0.8 \mathrm{~b}$ & $1.7 \mathrm{~b}$ \\
& T3 & $0.1 \mathrm{~b}$ & $2.4 \mathrm{~b}$ & $1.6 \mathrm{~b}$ \\
\hline
\end{tabular}

Note: The treatments were as follows: T1 (replacing the topsoil from $0 \sim 15 \mathrm{~cm}$ with the subsoil from $15 \sim 30 \mathrm{~cm}$ ), T2 (replacing the topsoil from $0 \sim 20 \mathrm{~cm}$ with the subsoil from $20 \sim 40 \mathrm{~cm}$ plus subsoiling at the 40 55 cm layer), T3 (replacing the topsoil from $0 \sim 20 \mathrm{~cm}$ with the subsoil from $20 \sim 40 \mathrm{~cm}$ plus subsoiling at the $40 \sim 70 \mathrm{~cm}$ layer) and CK (rotary tillage within $15 \mathrm{~cm}$ ). Different small letters indicated significant difference between treatments within the same year 


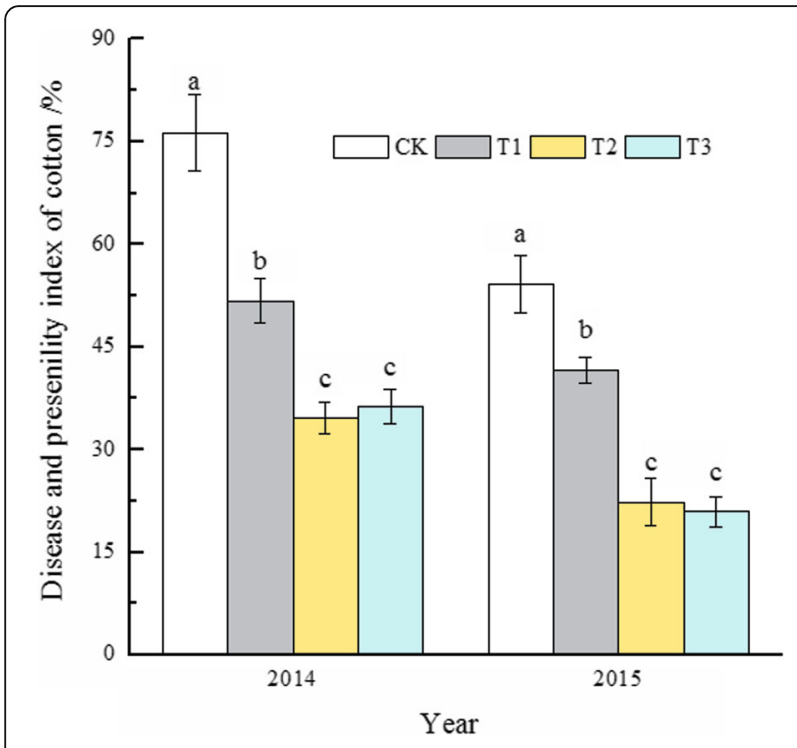

Fig. 10 Disease and presenility index (DPI) of cotton in different treatments in 2014 and 2015

primarily caused by surface evaporation. In addition, in the central and southern areas of Hebei Province, China, 9 drought years occurred within a 10-year span during midand late June (the square formation stage) when the cotton was susceptible to drought stress; a lack of water supply can lead to cotton leaf senescence at the late growth stage in rotary tillage (Rodriguez-Uribe et al. 2014). However, soil replacement plus subsoiling provided a larger water supply to the cotton in the middle and deeper soil layers during the budding stage, and the cotton growth was not found affected by drought in 2014. During a drought, the soil water within the deep soil layer in the soil replacement plus subsoiling treatments could move upward and be used fully by the cotton plant. In the rainy year of 2015, soil replacement plus subsoiling allowed water to accumulate in the middle and deeper soil layers, reduced surface evaporation, and improved the water buffering capacity of the soil, providing a greater water supply for cotton growth.

Few studies have been conducted on the effects of deep tillage and subsoiling on soil nutrients. Zhan et al. (2014) concluded that deep tillage and subsoiling increased the total and available $\mathrm{N}$ and $\mathrm{P}$ in the soil and promoted the release of available $\mathrm{K}$ into the soil. $\mathrm{Li}$ et al. (2007) showed that the available N, P, and K decreased with an increase in the soil bulk density in the deep soil layers, and deep tillage promoted the growth and accumulation of dry matter in maize during the late part of the growth stage. Feng et al. (2014) indicated that harrow tillage and rotary tillage could adjust the soil $\mathrm{C}$ and $\mathrm{N}$ conditions for the winter wheat-summer maize cropping system. In the present study, with respect to cotton growth and development, as the soil replacement plus subsoiling treatment replaced the topsoil from 0 to 20 with the subsoil from 20 to $40 \mathrm{~cm}$, the soil nutrients and microbial activity of the topsoil were poorer, thus delaying the cotton growth during the seedling and square formation stage compared with the growth stages under conventional rotary tillage. However, the soil water supply during this stage was enough. After the square formation stage, the cotton roots elongated and gradually entered the nutrient-rich soil layer below $20 \mathrm{~cm}$, which was in the drought stage in the conventional years. Soil replacement plus subsoiling improved the water and nutrient supplies in the middle and deeper soil layers. It was also beneficial for cotton roots growing downward and for accelerating the growth of the cotton plant. At the initial flowering stage, the aboveground dry matter accumulations of cotton in the soil replacement plus subsoiling treatments and the conventional rotary tillage treatment were the same. However, compared with rotary tillage, soil replacement plus subsoiling promoted downward cotton root growth during the late stage of the growth stage. The developed root system improved the drought resistance of cotton.

Few studies have been conducted on the effects of deep tillage and subsoiling on the occurrence of weeds. Liu et al. (2010) found that deep tillage could reduce the incidence of Verticillium wilt in soil, and the occurrence of wilt was less frequent than it was in conventional cotton fields. Wan et al. (2015) found that deep tillage could not effectively suppress the occurrence of tobacco bacterial wilt disease; instead, deep tillage increased the severity of the disease. In their study, they blended soil from different layers during deep tillage. In the present study, soil replacement plus subsoiling replaced soil at the $20-40 \mathrm{~cm}$ and $0-20 \mathrm{~cm}$ soil layers and exerted an extremely strong inhibitory effect on the occurrence of Verticillium dahliae and leaf senescence during the late growth stage of cotton. However, soil replacement plus subsoiling showed apparent advantages in terms of weed control, which was another important aspect of its superiority to deep tillage and subsoiling technology.

In this study, soil replacement plus subsoiling provided a new solution to overcome many shortcomings of rotary tillage in continuously cropped cotton fields.

\section{Effects of soil replacement plus subsoiling on crop yields}

Busscher et al. (2012) indicated that deep tillage improved cotton yield in the first year, but tilling in the second year marginally improved yield. Khalilian et al. (2017) also reported that deep tillage increased cotton lint yields compared with no-till, and there was no difference in lint yield between plots that were deep-tilled in all 3 years and those that were tilled only in the first year of the test. Reeves and Mullins (1995) reported that subsoiling was necessary for maximum cotton yields on 
coastal plain soils with root-restricting hardpans. Borghei et al. (2008) and Singh et al. (2019a, 2019b) also reported that subsoiling improved soil productivity and cotton yield. However, Khalilian Akinci et al. (2004) documented that the subsoiling treatments created statistically significant effects on the soil texture but did not affect cotton yield. In this study, soil replacement plus subsoiling exerted positive effects by reducing the soil bulk density, regulating the soil water supply, and balancing the vertical distribution of nutrients. Among the 3 soil replacement plus subsoiling treatments, the effects of $\mathrm{T} 2$ and $\mathrm{T} 3$ were greater than those of $\mathrm{T} 1$ in regard to enhancing the cotton yield and soil water stored in the deep soil layer and inhibiting cotton diseases and leaf senescence. The effect of T3 on the water supply capacity of the soil during the dry season was slightly better than that of $\mathrm{T} 2$ because its subsoiling depth reached $70 \mathrm{~cm}$. During the rainy season, the higher amount of stored soil water in T3 provided an abundant water supply for cotton and led to vigorous vegetative growth and a reproductive imbalance. Therefore, the effect of $\mathrm{T} 2$ on increasing cotton yield during the rainy season was stronger than that of $\mathrm{T} 3$. The highest lint yield was observed in T3 in 2014, which was attributed to the effect of the T3 treatment on the soil water supply. Drought led to a higher lint percentage in CK. The lint yield of T3 was lower than that of T2 in 2015 because of the vigorous growth of the cotton due to the higher soil moisture, which led to a smaller difference in the lint percentage between $\mathrm{T} 2$ and $\mathrm{T} 3$.

\section{Conclusion}

Soil replacement plus subsoiling reduced the soil bulk density in different soil layers, helped to distribute the nutrients evenly in different soil layers, promoted downward cotton root growth and improved the aboveground dry matter accumulation. This approach also inhibited cotton diseases and leaf senescence, reduced field weeds, and increased the number of bolls per square meter, the boll weight, and the lint yield. Therefore, it was an effective tillage measure for releasing some problems of severe disease and decreasing soil water supply capacity and lint yield in a continuously cropped cotton field. In this study, replacing the topsoil from 0 to 20 with the subsoil from 20 to $40 \mathrm{~cm}$ and subsoiling the $40-55 \mathrm{~cm}$ layer provided the best outcome.

\section{Acknowledgements}

The authors are grateful for the work of the technicians at the experimental station of the Institute of Cotton, Hebei Academy of Agriculture and Forestry Sciences.

\section{Authors' contributions}

Dong $H L$, Lin $Y Z$, and Wang SL designed the study. Li PC wrote the main manuscript text and prepared all figures. Qi H, Wang Y, Zhang Q, Feng GY, Zheng CS, and Yu XK carried out the experimental work and Wang SL and Li PC analysed data. All authors reviewed the manuscript. All authors read and approved the final manuscript.

\section{Funding}

This research was financially supported by The National Key Research and Development Programme of China (2017YFD0200107), the earmarked fund of the China Agricultural Research System of China (CARS-18-17), the National Natural Science Foundation of China (31701380) and the Natural Science Foundation of Hebei Province (2015301051).

\section{Availability of data and materials}

The datasets used and analysed during the current study are available from the corresponding author on reasonable request.

\section{Ethics approval and consent to participate}

Not applicable.

\section{Consent for publication}

Not applicable.

\section{Competing interests}

The authors declare that they have no competing interests.

Received: 1 July 2019 Accepted: 5 November 2019

Published online: 31 December 2019

\section{References}

Akinci I, Cakir E, Topakci M, et al. The effect of subsoiling on soil resistance and cotton yield. Soil Tillage Res. 2004;77:203-10. https://doi.org/10.1016/j.still. 2003.12.006.

Aulakh JS, Price AJ, Balkcom KS. Weed management and cotton yield under two row spacings in conventional and conservation tillage systems utilizing conventional, glufosinate-, and glyphosate-based weed management systems. Weed Technol. 2011;25:542-7. https://doi.org/10. 1614/wt-d-10-00124.1.

Borghei AM, Taghinejad J, Minaei S, et al. Effect of subsoiling on soil bulk density, penetration resistance, and cotton yield in northwest of Iran. Int J Agric Biol. 2008;10(1):120-3 http://agris.fao.org/agris-search/search.do?recordID=PK2 008000898.

Busscher WJ, Bauer PJ. Soil strength, cotton root growth and lint yield in a southeastern USA coastal loamy sand. Soil Tillage Res. 2003;74:151-9. https:// doi.org/10.1016/j.atill.2003.06002.

Busscher WJ, Khalilian A, Jones MA. Tillage management for cotton in se coastal soils during dry years. Commun Soil Sci Plan. 2012;43(19):2564-74. https:// doi.org/10.1080/00103624.2012.711878.

Clewis SB, Wilcut JW, Porterfield D. Weed management with smetolachlor and glyphosate mixtures in glyphosate-resistant strip- and conventional-tillage cotton (Gossypium hirsutum L.). Weed Technol. 2006;20:232-41. https://doi. org/10.1614/WT-05-030R.1.

Dai J, Dong H. Intensive cotton farming technologies in China: achievements, challenges and countermeasures. Field Crop Res. 2014;155:99-110. https:// doi.org/10.1016/j.fcr.2013.09.017.

Dong H, Li W, Eneji AE, Zhang D. Nitrogen rate and plant density effects on yield and late-season leaf senescence of cotton raised on a saline field. Field Crop Res. 2012;126:137-44. https://doi.org/10.1016/j.fcr.2011.10.005.

Feng $Y$, Ning $T$, Li Z, et al. Effects of tillage practices and rate of nitrogen fertilization on crop yield and soil carbon and nitrogen. Plant Soil Environ. 2014;60:100-4. https://doi.org/10.4141/CJPS2013-313.

Harrison DF, Cameron KC, Mclaren RG. Effects of subsoil loosening on soil physical properties, plant root growth, and pasture yield. New Zeal J Agr Res. 1994:37:559-67. https://doi.org/10.1080/00288233.1994.9513095.

Holliday VT. In: Klute A, editor. Methods of soil analysis, part 1, physical and mineralogical methods (2nd edition). Madison: American Society of Agronomy, Agronomy Monographs; 1986. p. 1188 9(1). pp., $\$ 60.00$. Geoarchaeology An International Journal. 2010; 5(1): 87-9. https://doi.org/10. 1002/gea.3340050110.

Jin $H$, Li H, Wang X, et al. The adoption of annual subsoiling as conservation tillage in dryland maize and wheat cultivation in northern China. Soil Tillage Res. 2007;94:493-502. https://doi.org/10.1016/.jstill.2006.10.005.

Karamanos AJ, Bilalis D, Sidiras N. Effects of reduced tillage and fertilization practices on soil characteristics, plant water status, growth and yield of upland cotton. J Agron Crop Sci. 2004;190:262-76. https://doi.org/10.1111/j. 1439-037X.2004.00101.X. 
Kennedy CW, Hutchinson RL. Cotton growth and development under different tillage systems. Crop Sci. 2001;41:1162-8. https://doi.org/10.2135/cropsci2001. 4141162x.

Khalilian A, Jones MA, Bauer PJ, et al. Comparison of five tillage systems in coastal plain soils for cotton production. Open J Soil Sci. 2017;7:245-58. https://doi.org/10.4236/ojss.2017.710018.

Khalilian A, Sullivan MJ, Smith WB. Lateral depth placement and deep tillage effects in a subsurface drip irrigation system for cotton. National Irrigation Symposium Decennial Symposium. 2000.

Li CH, Mei PP, Wang Q, et al. Influences of soil bulk density in deep soil layers on absorption and distribution of nitrogen, phosophrous and potassium in maize (Zea mays L.). Sci Agric Sin. 2007;40:1371-8 (in Chinese with English abstract).

Li H, Pang HC, Ren TZ, et al. Effects of deep rotary-subsoiling tillage method on brown physical properties and maize growth in northeast of China. China Agr Sci. 2013:46:647-56 (in Chinese with English abstract). http://www. chinaagrisci.com/EN/10.3864/j.issn.0578-1752.2013.03.022.

Liu HY, Wang L, Nuerziya W, et al. Effect of deep plough on occurrence of cotton Verticillium wilt and microsclerotia distribution. Xinjiang Agric Sci. 2010;47: 932-5 (in Chinese with English abstract). https://doi.org/10.3724/SP.J.1142. 2010.40491.

Motavalli PP, Stevens WE, Hartwig G. Remediation of subsoil compaction and compaction effects on corn $\mathrm{N}$ availability by deep tillage and application of poultry manure in a sandy-textured soil. Soil Tillage Res. 2003;71:121-31. https://doi.org/10.1016/S0167-1987(03)00041-2.

Patrick WH, Sloane LW, Phillips SA. Response of cotton and corn to deep placement of fertilizer and deep tillage. Soil Sci Soc Am J. 1959;23:307-10. https://doi.org/10.2136/sssaj1959.13615995002300040024x.

Raper RL, Reeves DW, Shaw JN, et al. Benefits of site-specific subsoiling for cotton production in coastal plain soils. Soil Tillage Res. 2007;96:174-81. https://doi. org/10.1016/j.still.2007.05.004.

Reeves DW, Mullins GL. Subsoiling and potassium placement effects on water relations and yield of cotton. Agron J. 1995;87(5):847-52. https://doi.org/10. 2134/agronj1995.00021962008700050011x.

Rickerl DH, Touchton JT. Conservation tillage and subsoiling effects on cotton. Soil Tillage Res. 1986;8:331-40. https://doi.org/10.1016/0167-1987(86)90363-6.

Rodriguez-Uribe L, Abdelraheem A, Tiwari R, et al. Identification of droughtresponsive genes in a drought-tolerant cotton (Gossypium hirsutum L.) cultivar under reduced irrigation field conditions and development of candidate gene markers for drought tolerance. Mol Breeding. 2014;34:177796. https://doi.org/10.1007/s11032-014-0138-8.

Salih AA, Babikir HM, Ali SAM. Preliminary observations on effects of tillage systems on soil physical properties, cotton root growth and yield in Gezira scheme. Sudan Soil Till Res. 1998;46:187-91. https://doi.org/10.1016/s01671987(98)0032-4

Salinas-Garcia JR, Matocha JE, Hons FM. Long-term tillage and nitrogen fertilization effects on soil properties of an alfisol under dryland corn/cotton production. Soil Tillage Res. 1997;42:79-93. https://doi.org/10.1016/S01671987(96)01092-6

Schneider F, Don A, Hennings I, et al. The effect of deep tillage on crop yieldwhat do we really know? Soil Tillage Res. 2017;174:193-204. https://doi.org/ 10.1016/j.still.2017.07.005.

Singh K, Choudhary OP, Singh HP, et al. Sub-soiling improves productivity and economic returns of cotton-wheat cropping system. Soil Tillage Res. 2019a; 189:131-9. https://doi.org/10.1016/j.still.2019.01.013.

Singh K, Mishra SK, Singh HP, et al. Improved soil physical properties and cotton root parameters under sub-soiling enhance yield of cotton-wheat cropping system. Data Brief. 2019b;24:1-5. https://doi.org/10.1016/j.dib. 2019.103888 .

Tangyuan N, Bin H, Nianyuan J, et al. Effects of conservation tillage on soil porosity in maize-wheat cropping system. Plant Soil Environ. 2009;55:327-33. https://doi.org/10.17221/25/2009-PSE.

Wan C, Jiang ZM, Zhao XL, et al. Effects of deep-ploughing and soil amendment application on incidence of tobacco bacterial wilt. Tob Sci Technol. 2015;48: 11-5 (in Chinese). https://doi.org/10.16135/j.issn1002-0861.20150203.

Wang XB, Cai DX, Hoognoed WB, et al. Potential effect of conservation tillage on sustainable land use: a review of global long-term studies. Pedosphere. 2006; 16:587-95. https://doi.org/10.1016/s1002-0160(06)60092-1.

Wayne RD, Price AJ, Patterson MG. Evaluation of three winter cereals for weed control in conservation-tillage nontransgenic cotton. Weed Technol. 2005;19:731-6.
Wesley RA, Elmore CD, Spurlock SR. Deep tillage and crop rotation effects on cotton, soybean, and grain sorghum on clayey soils. Agron J. 2001;93:170-8. https://doi.org/10.2134/agronj2001.931170x.

Yang $X$, Pang HC, Li YB, et al. Effects of deep rotary sub-soiling tillage on the physical properties and crop growth of the sticky loamy soil in North China. Sci Agric Sin. 2013;46:3401-12 (in Chinese with English abstract). http://www. chinaagrisci.com/EN/10.3864/j.issn.0578-1752.2013.16.011.

Zhan XM, Peng J, Li XL, et al. Effects of tillage and crop residues incorporation on spring maize yield and physical and chemical properties of soil. Acta Agric Boreali-Sin. 2014;29:204-9 (in Chinese with English abstract). http://www. hbnxb.net/EN/Y2014/N29/13/204

Zheng CY, Cui SM, Wang D, et al. Effects of soil tillage practice on dry matter production and water use efficiency in wheat. Acta Agron Sin. 2011;37:143240 (in Chinese with English abstract). https://doi.org/10.1016/s18752780(11)60039-4

\section{Ready to submit your research? Choose BMC and benefit from:}

- fast, convenient online submission

- thorough peer review by experienced researchers in your field

- rapid publication on acceptance

- support for research data, including large and complex data types

- gold Open Access which fosters wider collaboration and increased citations

- maximum visibility for your research: over $100 \mathrm{M}$ website views per year

At BMC, research is always in progress.

Learn more biomedcentral.com/submissions 